Especial: Naturaleza amena y naturaleza agreste en las letras hispánicas

\title{
De lagos y lagunas en la ecopoesía hispánica contemporánea
}

\author{
Ronald Campos López \\ Universidad de Costa Rica, Costa Rica \\ roncalo1125@gmail.com \\ https://orcid.org/0000-0001-5168-8392
}

Recibido: 18 de marzo 2018

Aceptado: 30 de mayo 2018

\section{Resumen}

En atención de la ecopreocupación global y las problemáticas del agua, en este artículo se analiza, desde una perspectiva ecocrítica, los motivos de los lagos y las lagunas en una muestra de ecopoesía hispánica. El corpus textual incluye 48 poemas o fragmentos de estos, pertenecientes a los mexicanos Homero Aridjis, José Emilio Pacheco, Verónica Volkow, Alí Calderón, Efraín Bartolomé y Mario Zetune Puglisi; los nicaragüenses Pablo Antonio Cuadra, Ernesto Cardenal y Gioconda Belli; Ios costarricenses Laureano Albán, Julieta Dobles, Ani Brenes y Patrick Cotter; el colombiano Juan Carlos Galeano; el peruano Eduardo Chirinos; la uruguaya Ida Vitale; las argentinas Olga Orozco y Liliana Mainardi; el chileno Javier Campos; y los españoles Antonio Colinas, Fernando Valverde y Daniel Rodríguez. Esta escogencia múltiple permite, más que un estudio comparativo, un abordaje transnacional y transcontinental de la ecopoesía hispánica desde una visión holística, ya que interesa reconocer y poetizar los motivos naturales o problemas ecológicos según distintas prácticas estéticas y zonas geográficas.

Palabras clave: Literatura hispánica, ecopoesía, ecocrítica, lagos, lagunas

\section{About lakes and lagoons in contemporary Hispanic eco-poetry}

\section{Abstract:}

Attending the global eco-concern and water issues, this article analyzes, from Ecocriticism's perspective, the lake and lagoon subjects in a sample of Hispanic eco-poetry. The text corpus includes 48 poems or fragments of these. They belong to the Mexican Homero Aridjis, José Emilio Pacheco, Verónica Volkow, Ali

\section{(C) $\odot \Theta \odot$}

La Revista Estudios es editada por la Universidad de Costa Rica y se distribuye bajo una Licencia Creative Commons Atribución-NoComercial-CompartirIgual 3.0 Costa Rica. Para más información envíe un mensaje a 
Especial: Naturaleza amena y naturaleza agreste en las letras hispánicas

Calderon, Efrain Bartolome and Mario Zetune Puglisi; the Nicaraguan Pablo Antonio Cuadra, Ernesto Cardenal and Gioconda Belli; the Costa Rican Laureano Alban, Julieta Dobles, Ani Brenes and Patrick Cotter; the Colombian Juan Carlos Galeano; the Peruvian Eduardo Chirinos; the Uruguayan Ida Vitale; the Argentinian Olga Orozco and Liliana Mainardi; the Chilean Javier Campos; and the Spanish Antonio Colinas, Fernando Valverde and Daniel Rodriguez. This multiple choice allows, more than a comparative study, a transnational and transcontinental approach of the Hispanic ecopoetry from a holistic viewpoint, because it is interesting in recognizing and poeticizing natural motifs and ecological problems according to different aesthetic practices and geographic areas.

Key Words: Hispanic literature, ecopoetry, Ecocriticism, lake, lagoon

\section{HACIA LA ECOPOESÍA HISPÁNICA}

La preocupación por las fuentes y abastecimiento de agua, así como por su conservación y renovación, son problemáticas actuales en un mundo que, poco a poco, se va convirtiendo en una biosfera caótica por causa de los intereses políticos y económicos de las sociedades (pos)modernas sin importar —como dice Paz (1990) - cuáles sean las creencias, opiniones, instituciones políticas y sociales de las naciones del orbe.

Ante las problemáticas del agua, y demás crisis ecológicas mundiales, ¿qué función tiene la literatura? Zapf $(2002,2010)$ responde que aquella es, por un lado, un sensorio de cuanto anda mal en la sociedad, las implicaciones biofóbicas que paralizan y convierten la vida en un producto de la consciencia y la civilización homogeneizantes; por otro lado, un medio de renovación cultural constante, en el cual las descuidadas y abandonas energías biofílicas pueden encontrar un espacio simbólico de expresión y (re)integración en la ecología de los discursos culturales.

Dicha respuesta solo es entendible desde la ecocrítica. Esta última estudia las relaciones entre la literatura y el medio ambiente (Glotfelty y Fromm, 1996). En tanto escuela de crítica, constituye un campo interdisciplinar, partiendo de la premisa ecológica de que todo está interconectado. Por eso, insiste en establecer

\section{(c) (i) (3)}

La Revista Estudios es editada por la Universidad de Costa Rica y se distribuye bajo una Licencia Creative Commons Atribución-NoComercial-CompartirIgual 3.0 Costa Rica. Para más información envíe un mensaje a 
Especial: Naturaleza amena y naturaleza agreste en las letras hispánicas conexiones y relaciones entre seres, especies, disciplinas, textos y lecturas; al tiempo que busca un compromiso ideológico, combinando teoría y crítica con la actividad creadora, docente y activista en torno a la educación ambiental. Así pues, articula un pensamiento ecológico constructivo. De ahí que, más que una ecocrítica, existan ecocríticas: diferentes aproximaciones estéticas, científicas, históricas, filosóficas, sociales, económicas, políticas, territoriales e ideológicas que (re)piensan las interacciones entre naturaleza y cultura en los textos literarios, de modo contingente, singular y transnacional (Buell, 1999; Flys Junquera, Marrero Henríquez y Barella Vigal, 2010; Forns-Broggi, 2012; Barbas-Rhoden, 2014; Donoso, 2015).

Desde 1998 la ecocrítica hispánicai ha sido titubeante en su lento camino por abrirse espacio al margen de los estudios y cánones literarios. Aquella se ha enfocado principalmente en la literatura hispanoamericana (Marrero Henríquez, 2010) y, específicamente, el desarrollo de los estudios enfocados en la ecopoesía contemporánea ha sido desigual en América Latina y España. Según Campos (2017), de 131 poetas hispánicos estudiados desde el enfoque ecocrítico hasta mayo de 2017, 116 (88,55\%) son latinoamericano y 15 (11,45\%), españoles. Aun así el desarrollo de tales investigaciones es asimétrico, pues tiende a concentrarse en prácticas ecopoéticas procedentes de Chile $(32,82 \%)$ y Perú $(18,32 \%)$. Asimismo, se observa una tendencia a la redundancia, ya que autores como Steven White, Roberto Forns-Broggi y Niall Binns, y sus estudios, se han convertido en referencias capitales e indispensables, lo cual lleva a que otros ecocríticos (re)visiten producciones en específico y repitan algunos presupuestos, observaciones y apreciaciones. De ahí que sobresalgan los análisis sobre las producciones de Nicanor Parra, Ernesto Cardenal, Gioconda Belli, Homero Aridjis y Pablo Antonio Cuadra. Además, no todas las prácticas de los poetas mencionados por los investigadores han sido abordados con la misma profundidad y detenimiento metodológico: algunas se quedan en el nivel de la cita o referencia

\section{(c) (i) (2)}

La Revista Estudios es editada por la Universidad de Costa Rica y se distribuye bajo una Licencia Creative Commons Atribución-NoComercial-CompartirIgual 3.0 Costa Rica. Para más información envíe un mensaje a revistaestudios.eeg@ucr.ac.cr. 
Especial: Naturaleza amena y naturaleza agreste en las letras hispánicas del poeta, un poema o un poemario, o bien el comentario general. Como temáticas analizadas predominan las relativas a los dones de la hospitalidad (16,50\%), la celebración $(14,56 \%)$ y el reparo $(12,14 \%)$, así como a la devastación ecológica $(12,14 \%)$.

Considerando, pues, estos datos y a algunos de dichos poetas y otros, este artículo se propone un recorrido por la ecopoesía hispánica contemporánea, a partir de los tópicos de los lagos y las lagunas. Como corpus textual se trabaja con una muestra de 48 poemas, cuyos autores son los mexicanos Homero Aridjis, José Emilio Pacheco, Verónica Volkow, Alí Calderón, Efraín Bartolomé y Mario Zetune Puglisi; los nicaragüenses Pablo Antonio Cuadra, Ernesto Cardenal y Gioconda Belli; los costarricenses Laureano Albán, Julieta Dobles, Ani Brenes y Patrick Cotter; el colombiano Juan Carlos Galeano; el peruano Eduardo Chirinos; la uruguaya Ida Vitale; las argentinas Olga Orozco y Liliana Mainardi; el chileno Javier Campos; y los españoles Antonio Colinas, Fernando Valverde y Daniel Rodríguez. Por el momento, existen estudios ecocríticos sobre la poesía de Aridjis, Pacheco, Cuadra, Cardenal, Belli, Albán, Galeano; algunas referencias sobre la ecopoesía de Volkow, Chirinos y Vitale; y apenas una mención sobre la de Colinas (Campos, 2017). Salvo en el caso de Cuadra y Cardenal, tales estudios, referencias y mención no abarcan los motivos aquí propuestos. De modo que el siguiente abordaje metodológico ofrece otras lecturas complementarias respecto de ellas, al mismo tiempo que brinda un primer acercamiento exploratorio a los textos de Calderón, Bartolomé, Puglisi, Dobles, Brenes, Cotter, Orozco, Mainardi, Campos, Colinas, Valverde y Rodríguez, desde la perspectiva ecocrítica.

Con base en esta múltiple escogencia de prácticas poéticas, se pretende no solo un análisis comparativo, sino también un estudio transnacional y transcontinental, puesto que la ecopoesía no se ocupa únicamente de asuntos nacionales o regionales, sino que, desde su visión holística, se interesa por reconocer y poetizar los motivos naturales o problemas ecológicos desde distintas estéticas y

\section{(๑) $\odot \odot$}

La Revista Estudios es editada por la Universidad de Costa Rica y se distribuye bajo una Licencia Creative Commons Atribución-NoComercial-CompartirIgual 3.0 Costa Rica. Para más información envíe un mensaje a revistaestudios.eeg@ucr.ac.cr. 
Especial: Naturaleza amena y naturaleza agreste en las letras hispánicas

zonas geográficas, rompiendo parámetros localistas con miras a una ecopreocupación global.

\section{ENTRE LAGOS Y LAGUNAS}

El humano es siempre un ser situado. Tener consciencia de este aserto lleva al ser a religarse con un lugar o varios, formar parte de él o ellos, porque el oikos (la casa o morada) es un espacio esencial para los humanos que, sobre todo, saben qué es el desarraigo y la alienación, mientras las otras especies habitan ecosistemas dentro de su territorio. La religación con el oikos o su búsqueda conduce al ser a sentir y percibir el lugar como un espacio subjetivo y, por ende, habitar un espacio cargado de significaciones, particularidades y valores (Buell, 2001; Binns, 2004).

Sin embargo, este proceder no garantiza una visión ecocéntrica del espacio. La ecocrítica se interesa por el ecocentrismo, según el cual el yo deja de percibirse como superior al entorno (Buell, 1995). Desde esta perspectiva, el oikos no se asumiría como un espacio pensado, sino como un mundo material tomado en sus propios términos e independiente de los valores asignadosii (Buell, 1995). De ahí que restablecer conexiones con los lugares, sin caer en idealizaciones ni conservadurismos, sea parte de los desafíos fundamentales de las sociedades contemporáneas y la ecopoesía (Binns, 2004).

Por lo anterior, la ecocrítica busca comprender mejor los paisajes y las regiones, a fin de desarrollar una teoría del lugar con base en tres perspectivas convergentes: el lugar como estructura simbólica, construcción social y ecológica (Buell, 1999). En respuesta de esto, tanto la ecopoesía como los textos ecologistas en general constituyen una literatura del estar (una en la que se incorpora la existencia concreta nutrida de la totalidad y hacia la cual se dirige) antes que una literatura del ser (una metafísica, neutral, abstracta, experimental, preocupada por

\section{(c) (i) (2)}

La Revista Estudios es editada por la Universidad de Costa Rica y se distribuye bajo una Licencia Creative Commons Atribución-NoComercial-CompartirIgual 3.0 Costa Rica. Para más información envíe un mensaje a revistaestudios.eeg@ucr.ac.cr. 
Especial: Naturaleza amena y naturaleza agreste en las letras hispánicas

idealidades y esencialismos, y, por lo general, desarraigada) (Binns, 2004; FornsBroggi, 2012).

Atendiendo a estos desafíos en torno al oikos, pues, se debe comenzar por trascender la idea del lugar como mero paisaje. Quizá esta sea la postura más desarrollada en la poesía hispánica. Guerra (2006) expone que los paisajes podrían presentar un valor ecocéntrico siempre y cuando sean tratados como como seres biológicos vinculados con la historia y existencia humanas y, por tanto, con la reafirmación de señas de identidad de una literatura propia. Por el contrario, carecerían de tal valor, si funcionan dentro de una hipotiposis de la naturaleza, espacios de evasión, locus amoenus, manifestación de color local o parte de una enumeración psicogeográfica de la realidad de una comunidad, provincia, país, región... Partiendo de esta disyuntiva, evalúense los siguientes casos.

\subsection{Evaluación inicial}

Primero, en un poemario paisajístico como Costa Rica poema a poema: un recorrido por el alma secreta de la patria, de Dobles, apenas se encuentran referencias de los lagos y lagunas nacionales. El sujeto lírico de "Retrato con volcanes" dedica dos versos a los lagos de cráter, su acidez y mineralización: "el Poás de los breves lagos verdes,/ inexcrutables [sic] en su basalto misterioso" (1997, p. 20). En "La pampa de todos los destellos", el sujeto lírico se refiere al volcán Arenal y, como parte de su entorno, cita al lago: "el Arenal, fantasma enhiesto en su cono y su lago/ con sus lavas nocturnas, como flores mortales" ( $p$. 70). El lago mayor de Costa Rica (aunque se trate de un embalse artificial creado sobre el viejo y pequeño lago homónimo) aparece circunscrito al paisaje volcánico, ni siquiera se lo vuelve centro de la enunciación poética. De esta forma, en los poemas de Dobles los lagos figuran como fragmentos secundarios de una hipotiposis.

\section{(C) $(00$}

La Revista Estudios es editada por la Universidad de Costa Rica y se distribuye bajo una Licencia Creative Commons Atribución-NoComercial-CompartirIgual 3.0 Costa Rica. Para más información envíe un mensaje a 
Especial: Naturaleza amena y naturaleza agreste en las letras hispánicas

Segundo, ocurre exactamente lo anterior en "El exiliado", de Cuadra, donde el actante lírico durante el recorrido de su destierro atraviesa distintos escenarios nicaragüenses y en un momento: "miró la luminosa extensión del Lago/ —del Padre Lago sonoro abierto en grito/ de aguas verdecol y riberas verdeantes" (2003, p. 285). Como señala White (2002), este exiliado ha perdido su oikos, experimenta el desarraigo y, por tanto, le es imposible establecer cualquier tipo de afiliación (topofílica o biofílica). Posiblemente esta falta o carencia de arraigo, conduzca a considerar el lago tan solo como un paisaje más. De forma similar se presenta el lago de Managua en el íncipit de "Caballos en el lago": como parte de un simple cuadro colorido y localista: "Los caballos bajan al amanecer./ Entran al lago de oro y avanzan/ —ola contra ola/ el enarcado cuello y crines—/ a la cegadora claridad./ Muchachos desnudos/ bañan sus ancas/ y ellos yerguen/ ebrios de luz/ su estampa antigua" (p. 30).

Tercero, en el poema "Parque nacionales", de Brenes, se presenta igualmente una referencia mínima o tangencial de los lagos del Poás en la construcción de una simple estampa: "Abre la tierra sus fauces/ en Barra Honda y sus cuevas, / y con grandes lagunas/ el Volcán Poás nos espera" (2008, p. 47). El fundamento objetivo de la prosopopeya inicial y el resto de la imagen quizá responda a que la producción lírica de Brenes está prácticamente compuesta y dirigida para niños; de ahí que se apueste por presentar de manera simplificada y verosímil espacios reales; al mismo tiempo que acercar de forma coloquial, rítmica y emotiva a los pequeños lectores a estas realidades, e introducirlos en la educación ambiental. Más adelante se ampliará este último punto.

Cuarto, casi dentro de los mismos términos anteriores de estampería, los lagos son dibujados con un tono meramente exótico en los siguientes versos de "Los cantos de ónice", de Colinas: "Ay los lagos colmados de lotos,/ los tejados color canela de China" (2008, p. 111).

\section{(c) (i) (2)}

La Revista Estudios es editada por la Universidad de Costa Rica y se distribuye bajo una Licencia Creative Commons Atribución-NoComercial-CompartirIgual 3.0 Costa Rica. Para más información envíe un mensaje a 
Especial: Naturaleza amena y naturaleza agreste en las letras hispánicas

Quinto, en el poema "Vista del valle de México desde Chapultepec, circa 1825", de Aridjis, se construye una imagen -o más bien un recuerdo idealizado- de tal paisaje, evocando la presencia del lago de Texcoco cuando aún gozaba de una rica masa acuosa. Sin duda, esta topografía configura un locus amoenus ahora ya perdido: "Caminos de álamos y olmos llevan a la ciudad,/ salen de la ciudad bañados por las aguas/ del lago de Texcoco, plateado de orillas" (White, 2014, p. $60)$.

Como se ve, en los cinco casos anteriores los lagos y lagunas aparecen como parte de una hipotiposis de la naturaleza; por tanto, son textos sin valor ecocéntrico.

Dando un paso más, puede que el uso del paisaje lacustre se quede tan solo en el nivel de un adorno, como sucede en la poesía de Belli. Esta poeta construye en el poema "América en el idioma de la memoria" un retrato genérico y simplista del continente con base en sustantivos comunes de especies vegetales, lagos, lagunas, aunque algunos pocos nombres propios de ríos. Al respecto los símiles: "Las palabras de los pueblos se parecen a sus montañas/ y a sus lagos,/ se parecen a sus árboles, a sus animales" (1997, p. 116). White (2010) señala que el esfuerzo lírico de Belli en este poema no alcanza el nivel de la tradición literaria hispanoamericana de reconocer el paisaje americano, especificar sus especies de flora y fauna, o nombrar accidentes topográficos concretos; una tradición que inició en 1826 con "Silva a la agricultura de la zona tórrida", de Andrés Bello, y ha alcanzado un desarrollo ecoliterario significativo en Canto general (1950), de Pablo Neruda, o bien Siete árboles contra el atardecer (1980), de Cuadra.

En el poema "Verde nostalgia", la hablante lírica retrata impresionista y melancólicamente Nicaragua: "Yo vi más de una vez/ nubes pasearse por el interior de mi casa./ Vi aguas del lago bruñir como plata fundida o plomo.// Hay un paisaje húmedo/ creciendo árboles de copas desaforadas en mi alma./ $\mathrm{Me}$ persigue/ con el dolor de un paraíso perdido" (2003, p. 95). Como se observa, se

\section{(C) $(0 \bigcirc)$}

La Revista Estudios es editada por la Universidad de Costa Rica y se distribuye bajo una Licencia Creative Commons Atribución-NoComercial-CompartirIgual 3.0 Costa Rica. Para más información envíe un mensaje a 
Especial: Naturaleza amena y naturaleza agreste en las letras hispánicas recurre metonímicamente al lago para configurar un espacio utópico, cuyos rasgos ecológicos también se desconocen. Con frecuencia, la nostalgia por el oikos perdido brota en forma de recuerdos, lamentaciones, idealizaciones o reconstrucciones imaginarias del espacio (Binns, 2004). Ello, sin duda, se manifiesta en estas dos estrofas. De esta manera, el adorno paisajístico sirve de antesala para una psicogeografía, o viceversa.

Debido, pues, a los símiles y el retrato anteriores, así como otros casos análogos, White (2010) concluye que en la poesía de Belli se manifiesta una homogeneización del medio ambiente como adorno en términos genéricos, ya que está compuesta desde una perspectiva antropocéntrica que evidencia cierta insensibilidad ante la diversidad natural.

Belli, no obstante, parece recurrir a los lagos y lagunas en términos casi topofílicos. Tuan (1974) define topofilia como los vínculos humanos afectivos con el medio ambiente o una zona biótica específica. En los poemas "Metamorfosis" y "Huellas", Belli define un espacio por medio de lugares nicaragüenses; respectivamente canta: "Mi conciencia está llena de lagos. Imágenes./ La bahía de San Juan del Sur, Masaya, Nindirí,/ la somnolencia de Granada, los malinches en la carretera de Nandaime,/ la laguna de Apoyo, el Diriá y San Juan de Oriente..." (2003, p. 17); "el paisaje se me crezca por dentro/ que el lago se me instale en los pulmones" (p. 31). Esta construcción del espacio se debe a que el sujeto lírico traza una doble vida geográfica entre Nicaragua y Estados Unidos. De ahí que, desde una perspectiva geocéntrica, establezca vínculos con su país natal y su país de domicilio, a fin de representar y construir una identidad y conciencia divididas en dos zonas bióticas (White, 2010). Sin embargo, este segundo tratamiento de Belli respecto de los lagos y lagunas no dista del anterior, pues se evidencia mayormente el antropocentrismo.

La psicogeografía teñida de nostalgia se puede encontrar de forma similar en "Mi casa junto al lago", de Cuadra. En este poema, se (re)construye e idealiza el 
Especial: Naturaleza amena y naturaleza agreste en las letras hispánicas

oikos, por medio de un presente edénico, un deseo utópico nacional y continental, y un recuerdo de una historia personal que pareciera sinécdoque de una historia nacional o continental de nuevo, debido a las referencias a dos de las herencias principales del ser hispánico (lo hispano-cristiano y lo indoamericano):

Aquí donde vivieron un día nuestros padres -mis padres los de tierra, mis padres los del marlos que vinieron de Cádiz y los que llegaron de Tula Aquí donde descansan los que una vez soñaron que podían vivir como hermanos en paz Aquí, junto al camino, donde América pasa y se queda en suspenso oyéndonos cantar; en esta vieja casa en el borde del Lago donde una barca invite siempre a navegar, en esta casa amiga donde amarra su caballo el campesino que llega a comprar a la ciudad:

Aquí estaré como siempre, hasta que venga la muerte y al pedirme posada se la tenga que dar. (2003, p. 254).

En "El maestro de Tarca (VII)", Cuadra asimismo presenta el lago como un adorno psicogeográfico para proyectar una experiencia sociopolítica del pueblo y la realidad nicaragüenses. El sujeto lírico usa el lago no solo para afirmar la lucha contra la dictadura somocista, sino también para profetizar su esperanza ante la guerra: "En el rencor del lago/ me parece oír/ la voz del pueblo" (2003, p. 86). Como afirma Íncer Barquero (2003), el lago suele constituir el escenario predilecto de Cuadra para legitimar al nicaragüense.

En fin, la utilización de lagos y lagunas como adornos o psicogeografías se presta para la inscripción de la mirada antropocéntrica y racional. Esta se puede encontrar claramente en la poesía de Colinas, Chirinos y Cuadra.

Por un lado, el motivo lacustre ha llevado a Colinas a hundirse en los lagos de la tradición literaria, a beber de las fuentes románticas y prerrománticas, para remontarlos a una visión neorromántica y culturalista propia de su estética (Nana Tadoun, 2008; Ferrán, 2017). Tal motivo se puede rastrear en una larga lista de

\section{(C) $(0 \bigcirc)$}

La Revista Estudios es editada por la Universidad de Costa Rica y se distribuye bajo una Licencia Creative Commons Atribución-NoComercial-CompartirIgual 3.0 Costa Rica. Para más información envíe un mensaje a 
Especial: Naturaleza amena y naturaleza agreste en las letras hispánicas paratextos espaciales en poemarios como Junto al lago (1967), Preludios a noche total (1969), Sepulcro en Tarquinia (1975) o Astrolabio (1979). Dentro de los múltiples desarrollos que dicho motivo manifiesta en esta poética está el de configurar o participar de un paisaje o topografía, ya sea en términos generales como en el poema "III" de Junto al lago ("Hasta nosotros viene/ el humo, la frescura, los rumores, la plena/ canción del pescador perdido en la laguna./ Golpeando están las aguas sobre las rocas negras./ Un día te hablaré despacio de este sueño,/ de este intento imposible de acariciar la tierra/ y sentir su temblor, su corazón de nube", 2008, p. 19); o bien en términos más específicos como en "Lago de Trasimeno", donde se alude aun con tono impresionistas al lago homónimo localizado en la región de Umbría (Perugia, Italia). En este escenario, lo último que percibe y enuncia el sujeto lírico antes de morir —si se parte que él es uno de esos "16000 romani perirono malgrado i presagi funesti” que el epígrafe sugiere- es justamente una visión antropocéntrica del lago: "Sólo brillaste para mí un instante/ en la pútrida tarde de tormenta./ Me pareciste un relámpago verde/ sobre el mojado y tenebroso/ bosque de olivos.// (Fría esmeralda/ bajo luz muy negra.)" (2008, p. 120).

La misma mirada es evidente en "Ensoñación de Fabrizio del Dongo en Grianta", donde el sujeto lírico (cuyo nombre está dado desde el título, al aludir al personaje de la novela La cartuja de Parma, de Stendhal) es el centro del poema y circunscribe románticamente su estado anímico al paisaje conformado por los lagos glaciares de Garda, Mayor y Como, los tres más grandes al norte de Italia. En este sentido, el espacio lacustre refleja la plenitud interior del ser:

Desesperadamente, aquí, en el corazón de los tres lagos, hoy debo discernir sobre mi vida y, por última vez, sopesar los augurios. Desde el Lago de Como se alza una niebla pálida como una muerte, que va a entristecer, despacio y heladora, 
Especial: Naturaleza amena y naturaleza agreste en las letras hispánicas opulentos jardines, el tiempo de las barcas.

En el Lago Mayor se va petrificando la vaga luz verdosa de los invernaderos. En día se desvela hacia el Lago de Garda como un esplendor delicado y misericordioso provocado por miles de velas. (2008, p. 284)

Como se ve en los tres últimos poemas, el esteticismo culturalista de Colinas lleva al sujeto lírico a experimentar una fascinación por los lagos, viéndolos como parte de un panorama geográfico histórico.

No obstante, obsérvese que al referirse al lago Mayor en este último fragmento el sujeto lírico advierte una preocupación ecológica: el impacto ambiental de los invernaderos en las orillas lacustres. Dentro de los efectos colaterales de los invernaderos se encuentran 1) las modificación del terreno, que van desde las micronivelaciones para favorecer el drenaje hasta la intervención más profunda, cuando se rellena con granzón u otro material para colocar luego plástico y encima colocar contenedores y sustratos artificiales; 2) la incorporación de enmiendas como materia orgánica, encalado y lavado de sales que tienden a mejorar los suelos, pero afectan el resto del ecosistema; 3) el drenaje de estas aguas que, al ser vertidas en el lago, producen la eutrofización de este; 4) la ocupación de varias hectáreas bajo techo impide la infiltración del agua pluvial y, por consiguiente, la escorrentía erosiona los suelos; 5) el desecho o quema de plásticos (mangueras, techos, contenedores de sustratos y material de tutoraje) que no se someten a un programa de reciclaje; 6) el desecho de vegetales restantes de la poda, plantas al finalizarse el cultivo o frutos dañados por plagas o enfermedades (Hernández, S.f.).

La opaca y verdosa sinestesia de petrificación en el poema connota la extensa ocupación plástica de los invernaderos, la contaminación, el drenaje, erosión y petrificación de los suelos. Consecuentemente, se puede interpretar también la eutrofización del lago Mayor. Esta sinestesia, por tanto, corresponde a un guiño ético - consciente o inconsciente- que busca evidenciar y denunciar un daño

La Revista Estudios es editada por la Universidad de Costa Rica y se distribuye bajo una Licencia Creative Commons Atribución-NoComercial-CompartirIgual 3.0 Costa Rica. Para más información envíe un mensaje a 
Especial: Naturaleza amena y naturaleza agreste en las letras hispánicas ecológico, en medio de un poema que mayoritariamente es el desarrollo de un planteamiento antropocéntrico y donde la naturaleza parecía ser tan solo paisaje. Por otro lado, en el poema "Daughters of the Lonesome Isle", de Chirinos, el motivo del lago alcanza su mayor grado de conceptual a través de una poesía concreta. Este poema pertenece a Breve historia de la música, un poemario en que Chirinos compone homenajes a algunas de las piezas musicales que más le gustaban. Su composición se da por imágenes que brotan de cada pieza y tienden a configurar un argumento. El susodicho poema es dedicado a la obra homónima de John Cage, escrita en 1945, para una danza de Jean Erdman. Como parte de tal poema, aparecen los versos:

\author{
En Pomona \\ preguntaste por el lago \\ un lago \\ es un lago \\ es un lago $(2001$, p. 74$)$
}

Pomona es una ciudad sita al sureste en el condado de Los Ángeles, California. Cerca de ella se encuentran el lago aluvial Lake Mission Viejo, el embalse natural Crystal Lake; los embalses artificiales Puddingstone Reservoir, Lago Irvine y Embalse de Prado; así como el estanque Baldwin Lake. El poema de Chirinos no brinda referencia específica a ninguno de estos lagos; por el contrario, el lenguaje coloquial, los sangrados, la epífora y el paralelismo construyen una visión genérica y conceptual de los lagos.

Esta imagen lacustre es producto, en efecto, de una mirada racional que toma forma de poesía concreta, ya que esta pretende una expresión inmediata, directa, aunando lo visual con lo conceptual. En este tipo de poesía, la palabra adquiere relevancia estética, primero, por su acentuación fonética y comunicación vocal concentrada de su significado; segundo, por el valor gráfico asignado en el espacio que media entre las palabras (López Grandolí, 2008). En los versos

\title{
(c) (i) (2)
}

La Revista Estudios es editada por la Universidad de Costa Rica y se distribuye bajo una Licencia Creative Commons Atribución-NoComercial-CompartirIgual 3.0 Costa Rica. Para más información envíe un mensaje a revistaestudios.eeg@ucr.ac.cr. 
Especial: Naturaleza amena y naturaleza agreste en las letras hispánicas anteriores, se comprueba la inmediatez conceptual del término lago y la prescindencia de la unidad rítmico-formal del verso para apostar por una nueva configuración gráfica, donde aquel término aparece a modo de constelación, quizá para señalar la distribución de aquellos seis lagos antes mencionados en la zona de Pomona.

Por su parte, en "Pensamientos bajo la estrella", de Cuadra, el sujeto lírico, fijando su mirada (acaso posmodernista) sobre un lago, lo reduce ornamentalmente en una hipotiposis del paisaje: "Un Dios que se sienta en el portal bajo la noche;/ un Dios que mira titilar la estrella sobre el lago, en el portal bajo la noche;/ que mira como yo miro la noche y la estrella/ desde el portal de su casa y junto al lago (de Genezareth /o de Managua)/ y mira como yo miro después de un día de cansancio,/ después de un día de trabajo" (p. 318).

Lo hasta aquí expuesto exige preguntarse urgentemente: ¿son ecopoemas los textos donde los lagos y lagunas, por ejemplo, aparecen como parte de un paisaje, una psicogeografía o subordinados a un planteamiento antropocéntrico? Un ecopoema no es aquel donde los elementos naturales (lagos, lagunas, animales, vegetación...) jueguen un papel en la ambientación o representación del texto. Si fuera el caso, casi cualquier poema a lo largo de la historia podría considerarse como tal. Esto, por consiguiente, obliga a descartar los textos anteriores de Dobles, Brenes, Cuadra, Aridjis, Belli, Chirinos y Colinas, con excepción del "Ensoñación de Fabrizio del Dongo en Grianta". Este último texto demuestra que puede existir cierta tensión, y aun convivencia, entre el paisaje como parte de una hipotiposis, estampa, adorno o percepción racional, y el paisaje que en ocasiones permite inscribir una preocupación ecológica. A estos casos habría que acercarse con cierta claridad epistemológica, a fin de establecer hasta dónde llegan los límites del valor ecocéntrico. El ecocrítico debería releer los textos literarios, tratando de descubrir el grado de conciencia o inconciencia ecológica en él, o bien

\section{(C) $(\Theta \odot \odot$}

La Revista Estudios es editada por la Universidad de Costa Rica y se distribuye bajo una Licencia Creative Commons Atribución-NoComercial-CompartirIgual 3.0 Costa Rica. Para más información envíe un mensaje a 
Especial: Naturaleza amena y naturaleza agreste en las letras hispánicas la visión de mundo que ofrece (Paredes y McLean, 2000). Este panorama obliga a descartar igualmente como ecopoemas, por tanto:

1) Un alto porcentaje de composiciones de Cuadra donde insistentemente se recurre al lago como hipotiposis o estampa; verbigracia: "El Maestro de Tarca (III)", "Angelina en el acantilado", "El aserradero de La Danta", "Calmura", "El miedo", "Mujer reclinada en la playa", "El abuelo", "Thállassa -memoria y navegaciones-", "Soneto a Granada", entre otros.

2) Aquellos de Colinas donde aparece el lago como la más significativa metáfora obsesiva del amor, su milagro y dolor, su espacio de ilusión y recuerdo (Nana Tadoun, 2008).

3) Los de Orozco, donde el lago igualmente funciona como metáfora o símil del (des)amor o el amante ("Tu corazón manando dura nieve es ahora más frío que la corola abierta en la escarcha del lago", 2000, p. 38; "Pero allí en el costado de los remordimientos/ los días sin vivir se abren como la onda de la piedra en el lago", p. 78) o bien fragmento de una metáfora existencial del ser ("Ah descubrir la imagen oculta e impensable del reflejo,/ la palabra secreta, el bien perdido,/ la otra mitad que siempre fue una nube inalcanzable desde la soledad/ y es toda la belleza que nos ciñe en su trama y nos rehace,/ una mirada eterna como un lago para sumergir el amor en su versión insomne,/ en su asombro dorado.", p. 204).

4) El poema de Valverde "El lago", donde este continúa la tradición de funcionar como metáfora del desamor. Al respecto, dice la primera estrofa: "Esta nieve que pisas va a convertirse/ en barro/ y en el lago veré mi rostro sin el tuyo" (VV.AA., 2011, pp. 241).

5) Las metáfora lacustre en "Cambio de planes" de Rodríguez, ya que se utiliza, como en el caso de Orozco, para componer una visión

La Revista Estudios es editada por la Universidad de Costa Rica y se distribuye bajo una Licencia Creative Commons Atribución-NoComercial-CompartirIgual 3.0 Costa Rica. Para más información envíe un mensaje a revistaestudios.eeg@ucr.ac.cr. 
Especial: Naturaleza amena y naturaleza agreste en las letras hispánicas existencial humana ("Hay un lago que puede reflejar/ la angustia y la esperanza de su orilla,/ del que todo ha perdido,/ del que todo lo espera", VV.AA., 2011, p. 172).

Se dijo al inicio que la ecocrítica estudia las relaciones entre la literatura y el medio ambiente. ¿Por qué no estudiar también la falta de estas como en los casos anteriores? La ausencia de relación evidencia ya una posición y perspectiva ante el tema ecológico; posiblemente, de indiferencia y utilitarismo, promovidos por el especismo: la idea sobre la superioridad del homo sapiens como individuo autónomo y centro del universo; idea que, análoga al racismo y el sexismo, ha relegado a otras especies a un estatus inferior, ha creado jerarquías dentro de los reinos animal y vegetal $y$, en efecto, ha autorizado su explotación para satisfacer las necesidades - de alimento, medicinas, vestuario, entre otros- de la humanidad (Binns, 2004; White, 2014).

Con el propósito de ayudar a definir formal e ideológicamente un ecopoema, Buell (1995) distingue cuatro características: 1) la naturaleza (animales, plantas, lagos o lagunas...) están presentes, mas no formando un escenario para la historia humana, sino implicados de manera ecocéntrica; 2) el beneficio humano no es el único interés legítimo; 3) la responsabilidad humana hacia el medio ambiente es parte de la orientación ética del texto; 4) la voz poética es consciente del tiempo que vive, las implicaciones que ello conlleva y las relaciones con espacios naturales más allá de cualquier idea de dominación y control.

Asimismo, un ecopoema, al igual que cualquier otro ecotexto, manifiesta cierta conciencia ecológica, pero sin sacrificar los valores estéticos a favor de discursos homilísticos (Paredes y McLean, 2000). Suscribir la visión holística de la literatura ecologista a una postura ética destinada tan solo a denunciar los elementos que destruyen la biosfera y repercuten globalmente respondería más bien a un antropocentrismo moral; e implicaría, por consiguiente, la composición de panfletos ecologistas (Binns, 2004).

\section{(c) 100}

La Revista Estudios es editada por la Universidad de Costa Rica y se distribuye bajo una Licencia Creative Commons Atribución-NoComercial-CompartirIgual 3.0 Costa Rica. Para más información envíe un mensaje a revistaestudios.eeg@ucr.ac.cr. 
Especial: Naturaleza amena y naturaleza agreste en las letras hispánicas Los ecopoemas, entonces, dice Scigaj (1999), deberían ser poemas sustentables: textos que conscientemente son concebidos para tratar la sensibilidad y pensamiento ecológicos sobre el flujo y retención de energía, la renovación cíclica, el biorregionalismo, la interdependencia de los organismos dentro de un ecosistema, entre otros. Un ecopoema busca dar un mensaje acerca de la necesidad de reexaminar las relaciones entre el ser humano y el mundo-más-quehumanoiii; redundar tanto en una toma de conciencia sobre la necesidad de respetar y defender el entorno, así como en la búsqueda o aceptación de una ecuación vital nueva, en la que el ser humano no tenga privilegios con respecto a los demás seres vivos, ni derechos dictatoriales sobre el planeta (Paredes y McLean, 2000). En este sentido, la ecopoesía reconoce la naturaleza de una manera interdependiente y libre. Asimismo, crea un marco para que el sujeto lírico se comunique con lugares específicos y criaturas que habitan en estos. La ecopoesía comprende al mundo como una comunidad y se dirige a un público con la intención de avisar sobre los peligros que puede acarrear un mundo sobrecargado de consumismo y tecnología (Barella Vigal, 2010).

Aun así, como afirma Paz (1999), la poesía, en sus intentos por promover la supervivencia del planeta, tiene una función indirecta: recordar desde una postura crítica ciertas realidades enterradas, resucitarlas y presentarlas. Quizá este principio lleva a Chen (2015) a exponer que la ecología —y la ecopoesía igualno sea únicamente un recordatorio de los daños y excesos contra la naturaleza, sino que involucra, en el mejor de los casos, "una toma de posición acerca del individuo y sus posibilidades de desarrollo sostenible y acorde con prácticas de equidad y de tolerancia" (2015, p. 100).

\subsection{Hacia auténticos ecopoemas}

Partiendo de la anterior definición operacional de cuanto sí es un ecopoema, y en contraste con aquel antropocentrismo, el ecocentrismo de los lugares lacustres se

\section{(C) $(\Theta \odot \odot$}

La Revista Estudios es editada por la Universidad de Costa Rica y se distribuye bajo una Licencia Creative Commons Atribución-NoComercial-CompartirIgual 3.0 Costa Rica. Para más información envíe un mensaje a revistaestudios.eeg@ucr.ac.cr. 
Especial: Naturaleza amena y naturaleza agreste en las letras hispánicas va manifestando poco a poco dentro de un espacio de posibilidades enunciativas que va desde los paisajes geográficos y ecológicos per se hasta los espacios de vida.

El primer caso estaría representado por textos de Volkow y Calderón. El poema "Río", de Volkow, ofrece en términos generales e impresionistas una topografía, en la que el lago se resalta como accidente geográfico en medio de una montaña. Sobre su espejo de agua el movimiento cromático del día se refleja y distingue. Dicha descripción se sustenta en el clásico tópico Ut pictura poesis:

El lago cambia de rostros como un espejo, en la tarde después de ser sol se vuelve algo metálico.

Ahora el lago es azul y paulatinamente transparente como aire cercano hacia los bordes. Entre la niebla el agua es una piedra la niebla cubre el bosque como un velo profundo pero por todas partes está abierta. (2013, pp. 21-22)

El valor ecocéntrico de esta topografía radica en que, por un lado, presenta al lago como accidente fluvial; y, por otro, el mismo movimiento cromático advierte sobre el peligro latente que se cierne sobre estos ecosistemas. El movimiento cromático permite contemplar el paso del tiempo. Ese tránsito desde lo azul (a veces metálico, a veces transparente según la luz) hacia lo opaco ("piedra"), y esa "niebla" que, aunque natural, podría connotar a manera de una falacia patética la contaminación que se avecina, sugerirían, o más bien llamarían la atención al lector, sobre la destrucción y desaparición que paulatinamente y cada vez más de prisa aquejan lagos y lagunas, hasta que entran irreversiblemente en el fluir temporal hacia su desaparición.

\section{(c) (i) (2)}

La Revista Estudios es editada por la Universidad de Costa Rica y se distribuye bajo una Licencia Creative Commons Atribución-NoComercial-CompartirIgual 3.0 Costa Rica. Para más información envíe un mensaje a 
Especial: Naturaleza amena y naturaleza agreste en las letras hispánicas

"Lago Lucerna" es el segundo poema de la serie titulada "Postales", de Calderón: "Gélido/ el lago,/ espejo/ del cielo:/ Inmaculada/ imagen/ de la transparencia" (VV.AA., 2011, pp. 303-304). Como se ve, el epíteto tipificador, la metáfora y la pintoresca topografía tejida sobre el núcleo sinecdótico de la "transparencia" articulan por yuxtaposición una imagen paisajística del lago tectónico y glaciar también llamado el de los Cuatro Cantones, sito en el centro de Suiza. A diferencia del poema anterior, este sí especifica un punto geográfico concreto. Aquellas tres figuras retóricas ponderan uno de los tipos de origen de dicho lago, el flujo de hielo que lo alimenta, la superficie blanquiazul y especular que del cielo brindan sus 114 $\mathrm{km}^{2}$; así como, metonímicamente, la limpidez y claridad de sus aguas y, metafóricamente, el reposo, la inmersión en lo indefinido y la morada que sus aguas ofrecen. En este breve y preciso poema, pues, se concentra el paisaje de este accidente fluvial y la amplitud de su valor ecocéntrico.

Este poema invita al lector a respetar la integridad de los lagos y a superar la idea de especismo, por la que el ser humano cree que puede llegar ante este paisaje y subordinarlo a sus necesidades de sobrevivencia y consecuente explotación. La visión condensada del lago de Lucerna, por tanto, incita a cuidar y conservar los paisajes lacustres en tanto ecosistemas fluviales, o bien a ejecutar en relación con ellos políticas y medidas de desarrollo sostenible.

A pesar de que el poema de Volkow se refiera en términos generales a los lagos sin especificar ninguno o a que el poema de Calderón forme parte de una serie llamada "Postales", en ambos textos el paisaje lacustre dista de considerarse mera hipotiposis, estampa, adorno, psicogeografía o concepto. En los dos se reconoce el valor geomorfológico de los lagos a manera de espejos de agua, sobre todo, por la transparencia y calidad de su masa.

Como ilustración de los lagos en tanto espacios vivos, se encuentran poemas de Aridjis y Brenes.

\section{(c) (i) (-)}

La Revista Estudios es editada por la Universidad de Costa Rica y se distribuye bajo una Licencia Creative Commons Atribución-NoComercial-CompartirIgual 3.0 Costa Rica. Para más información envíe un mensaje a 
Especial: Naturaleza amena y naturaleza agreste en las letras hispánicas

El primero se refiere a la laguna San Ignacio, sita al sur de Baja California, proclamada en 1988 Reserva de la Biosfera El Vizcaíno; en 1993, Patrimonio de la Humanidad; en 2004 incluida en la lista de sitios Ramsariv. En "El ojo de la ballena", el sujeto lírico concreta la vitalidad de este entorno a través de su biodiversidad: "Y Dios creó las grandes ballenas/ allá en Laguna San Ignacio,/ y cada criatura que se mueve/ en los muslos sombreados del agua./ Y creó al delfín y al lobo marino, a la garza azul y a la tortuga verde, al pelícano blanco, al águila real/ y al cormorán de doble cresta" (White, 2014, p. 79). Los 16 kilómetros de extensión y 5 millas de anchura de esta laguna motivan en el sujeto lírico el pensamiento de que esta, en efecto, es un santuario, no solo por la vida silvestre que alberga en el presente, sino aun porque se trataría del lugar donde míticamente Dios creó "los grandes monstruos marinos y todo ser viviente que se mueve, de los cuales están llenas las aguas según su género, y toda ave según su género" (Génesis 1: 21). Este presupuesto mítico, por un lado, representa la laguna como un mundo de interconexiones e interdependencias ecológicas; por otra parte, deconstruye el especismo que el propio Génesis bíblico ha contribuido a legitimar en el humano, ser que ni siquiera aparece como referente principal del poema.

En segundo lugar, Brenes ofrece el poema "Húmeda vida", en el cual se presentan diferentes lugares acuáticos como espacios vivos: "Lago, charquito,/ poza, manglar,/ agua escondida/ en todo lugar.// Húmeda vida/ casa y comida,/ es el trabajo/ del humedal" (2008, p. 1). Si bien el tópico por tratar aquí es el lago, Forns-Broggi (2012) afirma que el humedal podría analizarse análogamente como el lago, a pesar de que aquel no es un lugar habitual dentro de la literatura latinoamericana. No obstante, en el poemario de Brenes el humedal sí ocupa un lugar primordial y responde a una ética ecológica: dicho poema abre el libro y fue compuesto en conmemoración del 2 de Febrero o Día Mundial de los Humedales. Estos corresponden a espacios de dimensiones multivalentes, ya que almacenan

\section{(๑) $\odot \odot$}

La Revista Estudios es editada por la Universidad de Costa Rica y se distribuye bajo una Licencia Creative Commons Atribución-NoComercial-CompartirIgual 3.0 Costa Rica. Para más información envíe un mensaje a revistaestudios.eeg@ucr.ac.cr. 
Especial: Naturaleza amena y naturaleza agreste en las letras hispánicas agua, filtran desperdicios tóxicos, previenen inundaciones y hospedan especies de flora y fauna. Este último valor es justamente el poetizado con los propósitos de: 1) concretar por igual a lagos y humedales como espacios vivos; 2) educar sobre las relaciones de interconexión e interdependencia ecológica que se manifiestan en estas zonas bióticas: 3 ) concientizar y sensibilizar sobre la importancia, fragilidad y cuidado de estos ámbitos húmedos; 4) involucrar a los lectores en el rescate de tales espacios.

La literatura en la etapa infantil pretende ayudar a los niños a identificarse con el entorno, para que poco a poco desarrollen empatía por él; en este sentido, el componente visual, como recurso paratextual, cumple un rol significativo: vehiculizar en la fase prelectora el primer mensaje (Sarlo, 2017). De ahí que el poema de Brenes se vea acompañado, en un grado de interreferenciav ${ }^{v}$, por la figura 1, en la cual se representa a un humedal y clases de animales que suelen habitarlo (artrópodos, aves, reptiles, batracios, crustáceos y moluscos). Tal figura se ubica a la izquierda de la página, de modo que la imagen dialoga con el texto poético, interpela al lector e introduce una secuencia narrativa complementaria al poema, con el fin de persuadir a los niños todavía más con respecto al tema ecológico.

Figura 1. llustración del poema "Húmeda vida"

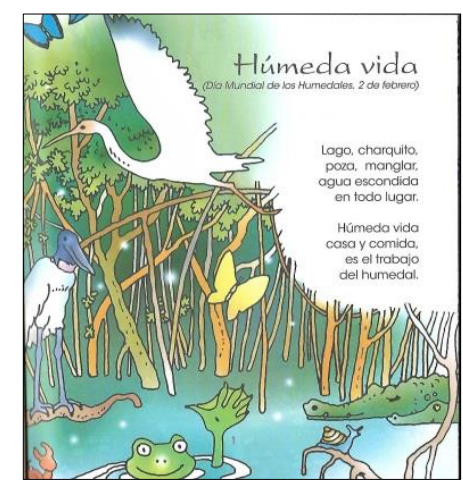

Fuente: Brenes (2008, p. 1)

\section{(๑) $\odot \odot \odot$}

La Revista Estudios es editada por la Universidad de Costa Rica y se distribuye bajo una Licencia Creative Commons Atribución-NoComercial-CompartirIgual 3.0 Costa Rica. Para más información envíe un mensaje a 
Especial: Naturaleza amena y naturaleza agreste en las letras hispánicas

Parte de la poesía infantil de Brenes, en efecto, participa del enfoque ecocrítico al dirigirse hacia la bioalfabetización. Como afirma González Muñoz:

No basta con enseñar desde la naturaleza utilizándola como recurso educativo, sino que hay que educar para el medio ambiente, hay que presentar y aprender conductas correctas hacia el entorno y no solo conocerlo. Se trata de un nuevo entendimiento de las relaciones del ser humano con el medio: la concepción de la naturaleza no como una fuente inagotable de recursos a nuestro servicio sino como un ecosistema frágil que tiene sus propias exigencias y que hay que respetar en nuestro propio interés. Se pasa así de objetivos psicológicos y didácticos a criterios de tipo ecológico (1996, p. 14).

La educación ambiental, según Frers (2010), es un proceso integral e interdisciplinario, cuyos objetivos son informar y preparar ecológicamente a la población, desarrollar actitudes y habilidades prácticas que mejoren la calidad de vida, el uso racional de los recursos naturales, y alcanzar un desarrollo sostenible que garantice la vida de las generaciones futuras. El anterior poema de Brenes, por tanto, bioalfabetiza y, siguiendo a Sarlo, busca la reflexión hacia fuera: acercar a los pequeños lectores a una literatura en la que "el tema del agua, de su respeto y de su cuidado, atañe directamente a la realidad medioambiental del entorno más o menos inmediato del niño" (2017, p. 224).

La posibilidad de poetizar los lagos y lagunas como espacios vivos puede llevar a considerarlos también como escenarios de una geopsique. Partiendo de Hellpach (1940), se entiende por geopsique la relación entre el ser humano, el suelo, el paisaje, el clima, la cultura y la historia, de modo que se incorporan integralmente elementos psicosociológicos y antropológicos; como resultado de esta relación, se llega a precisar una concepción del mundo y la vida en un espacio determinado. Este concepto de geopsique, sin duda, se puede asociar a la noción de placeconnectedness de Buell (2001).

Partiendo de dicho concepto, se puede observar cómo Cuadra, en "El maestro de Tarca (VI)", presenta a este maestro como un consejero para los isleños

La Revista Estudios es editada por la Universidad de Costa Rica y se distribuye bajo una Licencia Creative Commons Atribución-NoComercial-CompartirIgual 3.0 Costa Rica. Para más información envíe un mensaje a 
Especial: Naturaleza amena y naturaleza agreste en las letras hispánicas

recordándoles, con base en su tradición, lecciones de sobrevivencia y alimentación a partir de recursos que el lago les facilita. Sus consejos no se limitan a cómo sostener antropocéntricamente la vida usando la naturaleza; más bien, partiendo de tal necesidad, el sujeto lírico evidencia la geopsique, gracias a la cual el ser humano, en los períodos de escasez, aprende a beneficiarse de la abundancia del lago, de este gran organismo viviente, pero sin propasarse ni irrespetarlo: "-En el verano la tierra es secal y el agua está en su reino:/ toda aventura te permite/ el espejeante lago/ todo alimento te ofrecel benévolol (aunque teme/ siempre/ su inmotivada furia)" (2003, p. 72). En sus lecciones, el maestro de Tarca expresa una clara topofilia, puesto que identifica una variedad de especies que ocupa las zonas lacustres nicaragüense (gaspares, cangrejos, tamarindos, ñocas, tortugas, iguanas, mojarras, guapotes y guabinas), y enseña acerca de su valor etnozoológico.

Nótese la vivificación del lago como un ser biológico en la cita anterior de Cuadra. Esa prosopopeya indica que el valor de lo vivo ha permitido concebir igualmente lagos y lagunas personificados o animados en algunos ecopoemas.

Buell (1995) considera que la personificación de animales y plantas tiene que ver con la atenuación de las jerarquías entre el homo sapiens y las demás especies. Un caso de personificación se encuentra en el poema "La laguna", de Albán, donde esta aparece humanizada gracias a la prosopopeya: "La laguna no sabe/ que no es de este mundo,/ no sabe, no ha entendido,/ que ya ha bebido demasiado cielo/ para ser de este mundo,/ que ella no está en el prado/ devolviéndole orillas a la vida" (2010, p. 262). Aquella desconoce racionalmente su origen cósmico y sagrado. Para representar dicho origen, sus cualidades celestiales luminosas y su pertenencia a un plano superior al de las fuerzas formales o físicas del mundo profano, el sujeto lírico describe a la laguna con una etopeya: "Ella sólo es un lampo de luz/ que no duerme sobre el mundo,/ como si dijera/ que aquel agua se hizo profecía./ La laguna no está aunque siga aquí./ A

\section{(c) (i) (2)}

La Revista Estudios es editada por la Universidad de Costa Rica y se distribuye bajo una Licencia Creative Commons Atribución-NoComercial-CompartirIgual 3.0 Costa Rica. Para más información envíe un mensaje a revistaestudios.eeg@ucr.ac.cr. 
Especial: Naturaleza amena y naturaleza agreste en las letras hispánicas las cosas perfectas,/ los dioses se las llevan./ A los reinos de la niebla,/ los dioses se los llevan./ A las cosas que son/ visibles e invisibles a la vez,/ los dioses se las llevan" (p. 262). La laguna es presentada como materia primordial numinosa, pues manifiesta y es lo trascendente (cielo y agua); en este sentido, ella constituye una hierofanía; y, por las connotaciones del agua y la luz, también es una hierogamia elemental, pues fecunda la tierra. La laguna en sí es un ente activo, contenedor de vida y perfección espirituales desde el principio ejemplar de la creación, por el hecho de ser parte de esta última. Ella es manifestación divina y partidaria de un proceso aún evolutivo informe y original. Sin embargo, no lo sabe. El sujeto lírico únicamente ratifica, desde una perspectiva deísta, que la laguna alberga un misterio por ser parte del cosmos y que ha descendido desde lo celestial hasta lo terrestre para participar, dentro de esta red, de un proceso evolutivo de perfección espiritual como un homo religiosus haría en su empresa mística. "El mundo necesita ser resacralizado. La poesía es el camino más libre y desinteresado para esa imprescindible resacralización” dice Roberto Juarroz (1997, p. 178). La poesía de Albán, desde sus comienzos, ha perseguido esta religación cósmico-sagrada.

El animismo como tal se puede observar en el poema "Un lago hace lo que puede", de Galeano. El propio poeta cuenta cómo, merced a que vivió su infancia en la Amazonía colombiana, aprendió "la filosofía de vida de los moradores de riberas y selvas para quienes los animales, ríos, lugares y cosas tienen alma y poder" (White, 2014, p. 111). Esta filosofía lo ha llevado a manifestar en su poesía: "Un animismo bueno para minar el egocentrismo y las construcciones antropocéntricas de nuestros días" (p. 111). Sin duda, puede identificarse este animismo como herencia cultural de los incas. Ellos creían en que prácticamente no existía ninguna materia inanimada; dicha creencia regía su mundo e idea de metempsicosis (Huber, 1961).

En el susodicho poema prosaico de Galeano, el sujeto lírico se comporta como un narrador heterodiegético al contar una historia natural de los lagos, a los cuales

\section{(c) (i) (2)}

La Revista Estudios es editada por la Universidad de Costa Rica y se distribuye bajo una Licencia Creative Commons Atribución-NoComercial-CompartirIgual 3.0 Costa Rica. Para más información envíe un mensaje a revistaestudios.eeg@ucr.ac.cr. 
Especial: Naturaleza amena y naturaleza agreste en las letras hispánicas describe mediante etopeyas: "A cualquier edad llevan la vida reposada de las personas al jubilarse.vi/ [...] Los lagos que desean un reposo verdadero contratan gigantes que los defienden. vii// Un lago es un solitario que no quiere problemas.// Filósofo disfrazado o cuerpo sumiso de ogros capitalistas, un lago hace lo que puede" (White, 2014, p. 121). Estas cualidades parecen atribuirse de manera indirecta o por asociación intratextual al protagonista del poema: Meditación, un lago que vive en las afueras de la ciudad. Para justificar el animismo de Meditación, el sujeto lírico crea una hipodiégesis: menciona la existencia de un filósofo llamado Suetoni Hanno, quien "escribió hace quinientos años en su Vida de los lagos acerca de espíritus diminutos que moran en los lagos con cuchicheos y risas"viii (p. 121). Esta historia parodia el nombre del filósofo latino Suetonio y el título de su Vidas de los doce césares. ¿Qué relación guarda este prosema con los textos de Suetoni y Suetonio? Los tres son textos biográficos que buscan confirmar la existencia, detallar caracteres y brindar anécdotas de Meditación, los lagos y los césares, respectivamente.

El sujeto lírico continúa narrando las relaciones que los humanos establecen con los lagos: "Al ser lugares tan amables para vivir, el sueño de muchos es retirarse junto a un lago. ${ }^{\mathrm{x} /}$ / Hay quienes usan un lago tranquilo para engordar peces. ${ }^{\mathrm{x}}$ Después construyen mansiones en otro lago" (p. 121). Como se observa, van desde la protección que las mismas mansiones a sus orillas les proveen a los lagos hasta el cultivo de peces en estos. Tales relaciones ofrecen dos lecturas posibles. La una en términos irónicos, pues la piscicultura y la tranquilidad de muchos rompen el reposo y soledad de los lagos, así como las edificaciones que buscan embellecer el lugar y aumentar su plusvalía, amurallan y degradan las orillas lacustres. La otra en términos positivos, ya que en ese ecosistema conviven recíprocamente lo humano y lo natural sin una separación tajante como la proclamada por la modernidad. Esta convivencia es posible si se entiende, como Riechmann (1997), que la biosfera es un sistema de todos los ecosistemas 
Especial: Naturaleza amena y naturaleza agreste en las letras hispánicas existentes. Pareciera que en sintonía con esta idea de biosfera el sujeto lírico pregunte retóricamente: “¿Qué tanto le gustaría al lago ser otra cosa, por ejemplo, una montaña, o un río y llegar hasta el mar?"; es decir, qué tanto le gustaría huir de esta situación aparentemente invasiva, a lo que Meditación responde: "En realidad, nada. Me gusta ser un lago" (p. 121). Con su respuesta final, Meditación, con su ánimo solitario y filósofo, se trae abajo la primera lectura.

White (2002) estudia el animismo igualmente en la poesía de Cuadra. Señala que en "Las bodas de Cifar" el afán ecocéntrico de la tradición folklórica indígena lleva a convertir al lago en un personaje dramático xi: "Ráfagas, turbiones,/ olas/ rayos/ el lago embravecido/ y negro nos golpeaba a muerte/ el barco y nos rompía/ las velas y las drizas" (2003, p. 65). Además, anota que en "El miedo" se presenta la frecuente estrategia de Cuadra por simbolizar el mundo-más-que-humano; en este caso, el lago se vivifica a modo de un felino: "No cuando el Lago/ irritado/ y pardo/ puma/ ruge,/ y su pesada zarpa/ hace crujir/ tu lancha" (2003, p. 75).

En fin, tanto la personificación como el animismo advierten, desde una perspectiva ya deísta, ya panteísta, ya simbólica, la presencia del mito del anima mundi: el alma del mundo, el espíritu etérico y puro, la causa del movimiento interior de un ente $u$ objeto de la naturaleza, igual a como el alma anima al ser humano. E anima mundi es la única fuerza vital trascendente que es todo en propósito y forma, pues infiere "la noción del universo como un ser viviente $y$, en consecuencia, la ausencia de un alma individual, ya que no existe una diferencia sustancial entre lo que anima al ser humano y a los demás objetos" (Campos, 2012, p. 327).

Este mito no solo vivifica al mundo, sino que invita a explorar las formas unitivas de lo humano con la naturaleza. A continuación, atiéndase cuatro casos.

En primer lugar, el sujeto lírico del poema "Lago Ohrid", de Aridjis, se refiere al lago homónimo, también conocido como Ocrida. Este se ubica al suroeste de la frontera entre Macedonia y Albania. Por sus 288 metros, es el lago más profundo

\section{(C) $(0 \bigcirc)$}

La Revista Estudios es editada por la Universidad de Costa Rica y se distribuye bajo una Licencia Creative Commons Atribución-NoComercial-CompartirIgual 3.0 Costa Rica. Para más información envíe un mensaje a revistaestudios.eeg@ucr.ac.cr. 
Especial: Naturaleza amena y naturaleza agreste en las letras hispánicas de los Balcanes. Asimismo, es uno de los más antiguos del mundo junto al Titicaca y el Baikal. El sujeto lírico poetiza la llegada de pueblos bárbaros al Ohrid, sus intentos de delimitar y controlar sus aguas ("Tomaron posesión de las aguas arrugadas [...]/ Pusieron fronteras en el agua, como si el agua/ pudiese ser dividida", White, 2014, p. 92); pero, aún más, su empresa mística de erigir "la profecía de sí mismos que querían oír" (p. 92); en otras palabras, escuchar y responder al llamado divino que a través de estas aguas les llegaba, pues qué es la profecía sino la contemplación intuición, el alto conocimiento que no se puede adquirir por vía racional, sino por símbolos o imágenes sensibles, como las de la audición. A propósito, obsérvese una relación intertextual de este poema con el de Albán, puesto que en ambos el agua lacustre se presenta como profecía. Continuando, recuérdese que la oreja es uno de los canales de la vida espiritual (Chevalier y Gheerbrant, 1988), que permite al homo religiosus percibir lo (in)audible y profundidad del misterio cósmico. Por lo anterior, aquellos pueblos bárbaros instauran en el Ohrid su "omfalos del mundo,/ aunque el mundo tiene muchos omfalos" (p. 92). Este lago, por tanto, pasa a ser un centro sagrado de $358 \mathrm{~km}^{2}$ de aguas inasibles e indivisibles donde lo solar (la epifanía uránica por excelencia) manifiesta su maiestas ${ }^{\text {xii }}$ y se sobrepone con un significado cósmico mayor aun sobre los humanos: "El lago permaneció inasible.// El sol como un ojo ebrio bailó sobre las ondas [...]// Hubo entonces una blancura más blanca que el blanco./ Y todos los árboles de la orilla miraron esa luz" (White, 2014, p. 92). Como se observa, se presenta de nuevo el lago como un espacio de conexión viva donde se conjugan lo mítico y lo sagrado de la naturaleza. El nexo entre literatura y naturaleza representa, así, la biofilia en términos de la unión primordial del ser

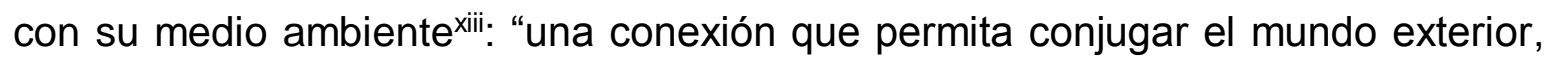
mítico y sagrado de la naturaleza con la subjetividad y el mundo social" (Ostria, 2008, p. 222). De ahí que, en este poema, el lago, en tanto espacio vivo, sea un

\section{(c) (i) (-)}

La Revista Estudios es editada por la Universidad de Costa Rica y se distribuye bajo una Licencia Creative Commons Atribución-NoComercial-CompartirIgual 3.0 Costa Rica. Para más información envíe un mensaje a 
Especial: Naturaleza amena y naturaleza agreste en las letras hispánicas ámbito continuo donde se borran las fronteras de la contingencia, se abre un umbral de lo sagrado y el ser humano armoniza con el cosmos.

Tanto aquel poema de Albán como este de Aridjis comprueban que, según afirma Boff (1996), las dimensiones de lo sagrado y la religión (la religación con todas las cosas) tienen un significado relevante ante la crisis ecológica. La clave se encuentra en el concepto de religación, pues permite recobrar los vínculos básicos y la idea de la vida como una red. Lo sagrado y lo religioso, por tanto, permiten recuperar un paradigma social arcaico, simbólico y arquetípico, en el que la concepción de armonía con la naturaleza y el entorno es fundamental.

En segundo lugar, Mainardi ofrece el dístico: "No es el mismo/ es parte del lago" (2015, p. 70). Esta concisa imagen funciona como sentencia, pues invita a compartir la verdad de que el ser humano y la naturaleza en realidad son uno solo, una sola materia continua e indiferenciada. Por su forma y contenido, la brevedad de este poema fácilmente recuerda a la del haiku. Cisneros Cox (1997) describe el haiku como el género lírico cuyo breve sistema se dirige a mantener una relación y un culto con la naturaleza; una visión clara y espontánea del mundo exterior, la cual se complace con el preciosismo del color y las formas de la naturaleza. Quizá Rosenfeld (2015) se haya valido de esta definición para señalar el espíritu de este género en la poesía de Mainardi. Ciertamente, resulta pertinente afirmar que el antedicho dístico dialoga con el haiku, o al menos posee su lógica, debido a su esfuerzo estructural e ideológico de sintetizar y enunciar como centro del poema la fusión del ser humano y el lago: la unidad cósmica.

En tercer lugar, y tomando aún en cuenta la obsesión amorosa que Colinas inscribe en torno al lago, del poema "IX" de Junto al lago se rescata un disecado sentimiento de fusión cósmica de los amantes, merced al cual ellos pasan a participar del tejido armonioso del ecosistema: "Vivir, amor, tendidos junto al lago/ como el junco a la orilla del arroyo; sentir las aguas claras y sentirte/ discurriendo

\section{(C) $(\Theta \odot \odot$}

La Revista Estudios es editada por la Universidad de Costa Rica y se distribuye bajo una Licencia Creative Commons Atribución-NoComercial-CompartirIgual 3.0 Costa Rica. Para más información envíe un mensaje a revistaestudios.eeg@ucr.ac.cr. 
Especial: Naturaleza amena y naturaleza agreste en las letras hispánicas muy pura ante mis ojos" (2008, p. 25). De nuevo un poema de Colinas se articula como espacio textual de tensión, esta vez entre lo psicogeográfico y lo biofílico.

En cuarto lugar, en el poema "Woodstock", de Campos, se escenifica la participación en el festival de música y arte homónimo de 1969. Esta congregación hippie permitió consolidar la contracultura de los 60 la cual, harta de la guerra, el sistema capitalista, el consumismo y el sentimiento de alienación, pregonaba la paz y el amor como formas de vida. El sujeto lírico canta:

La lluvia caía como cataratas

y construía en la tierra y en el pasto

lagos artificiales

que usaron para nadar desnudos, dejaron que sus cuerpos hermosos

se hundieran en cámara lenta y se bautizaron con el agua que venía del cielo como si fueran los humildes profetas de lejanas civilizaciones escondidas bajo la tierra para siempre

Se abrazaban transparentes de una misteriosa luz interior entraban y salían de esas lagunas artificiales con el corazón purificado limpiándose la mugre del alma creyeron que tocaban el origen humilde del Universo hicieron el amor sobre el pasto cubierto de barro y nadie preguntó nada a nadie nadie tampoco les apuntó con el dedo ni nadie llamó a la policía que vigilaba desde lejos en sus autos blanco y negro, con luces intermitentes que giraban como látigos de fuego (2008, pp. 39-40)

Los poetizados son claramente lagos y lagunas estacionales de origen pluvial, donde los participantes del festival viven —compenetrados con la tierra y el cielosu ecoespiritualidad: una práctica política de liberación y un paradigma otro de expresión religiosa (Forns-Broggi, 2012). En este sentido, podría interpretarse, por un lado, su desnudez como esa renuncia o contrarrespuesta al poder hegemónico y la insensibilidad capitalista y bélica que ha generado represión y exterminio 
Especial: Naturaleza amena y naturaleza agreste en las letras hispánicas humanos, así como desastres ecológicos. Estos lagos y lagunas pasan a ser su oikos, su casa no solo física sino también espiritual, esa morada donde el ser convive y cíclicamente se prolonga -en este caso por medio de rituales- en el tiempo y el espacio (Binns, 2014). Con la desnudez, se exalta bucólicamente el ecologismo. Por otro lado, el agua celestial aparece como símbolo diairético ${ }^{\text {xiv }}$, pues su depósito en forma de lagos y lagunas facilita la ablución. Por su parte, el amor erótico aparece como símbolo del progresoxv, puesto que connota tanto lo sagrado como la participación en la armonía cósmica. En este poema, por tanto, la ecoespiritualidad permite la manifestación de los dones de la celebración y la hospitalidad, justamente en la búsqueda de esa sintonía y comunión del ser con la naturaleza.

A propósito de lo anterior, recuérdese que Forns-Broggi (1998) estudia y propone cuatro dones que la naturaleza ha regalado a la ecopoesía latinoamericana: 1) el don del reparo, según el cual la poesía recurre a la ecología como arma crítica y analítica frente al proceso de modernización, observando también la desaparición de culturas; 2) el don de la celebración llama a proyectos abiertos y transversales de integración cósmica y sostenible, evitando la separación cultura / naturaleza; 3) el don de la hospitalidad posibilita el pensamiento ecológico como respuesta a la ilimitada capacidad de acogida del paisaje y la vida misma, entendiendo estos como oikos, pues albergan el entorno de lo interno; 4) el don de la voz femenina rehúye las imposiciones patriarcales y retrata lo femenino como fuerza dinámica e interdependiente con la naturaleza.

Sin entrar en detalles, Forns-Broggi (1998) menciona apenas la poesía de Volkow como ejemplo de este cuarto don. Los siguientes versos del poema "La mujer" vendrían a ilustrar dicho don: "Y ya es de carne el fuego/ y carne, el sol, el cielo,/ el lago, el prado, la montaña,/ y ya es de carne Dios/ en la mujer guardado" (2013, p. 95). El sujeto lírico representa el cuerpo de la mujer como un recipiente que guarda rastros del cosmos porque también ella es creación divina. Mientras su

\section{(C) $(0 \bigcirc)$}

La Revista Estudios es editada por la Universidad de Costa Rica y se distribuye bajo una Licencia Creative Commons Atribución-NoComercial-CompartirIgual 3.0 Costa Rica. Para más información envíe un mensaje a revistaestudios.eeg@ucr.ac.cr. 
Especial: Naturaleza amena y naturaleza agreste en las letras hispánicas mano es una estrella, su piel es luz y astros; y su carne tan inmensa como el universo y el numen. En este afán por construir su feminidad, la hablante lírica se homologa al lago y demás elementos de la naturaleza, pues no existe ninguna distinción ni separación entre su cuerpo y el resto de manifestaciones fenomenológicas y sagradas del cosmos. Por tanto, la luminosidad, extensión e inclusión del cuerpo femenino se opondrían a la invisibilización u opacidad, marginalidad y exclusión sexista que la mujer padece dentro del sistema patriarcal naturalizado. La hablante lírica estaría sustituyendo estos valores por un nuevo paradigma antinaturista propuesto desde el ecofeminismo: una valoración de lo cósmico con miras hacia una ética estructuralista de la mujer y ecología social nuevas ${ }^{x v i}$.

\subsection{Basta de ecopoemas positivos}

¿Qué pasa con el sentido de desarraigo, la pérdida del oikos y el deterioro ecológico? Tanto la ecología en general como la literatura ecologista indagan en el sentido de arraigo que los seres humanos tienen como factor central en la defensa de sus ecosistemas locales o regionales y en su persecución de una idea de totalidad - no como suma de partes, sino como red de relaciones entre las partes- (Paredes y McLean, 2000; Buell, 2001). Sin embargo, la escisión prevalece en el imaginario colectivo y caracteriza culturalmente a los siglos XX y XXI (Araújo, 1997). De ahí que el antropocentrismo y el egocentrismo se manifiesten en las nociones postmodernas de fragmentación, desarraigo y alienación del ser humano. La plasmación de estas nociones, no obstante, resulta esencial en última instancia para romper dramáticamente con ellas mismas y tratar de (re)incorporar al ser con lo contemplado en el flujo de la vida (Araújo, 1997; Binns, 2004).

\section{(c) (i) (-)}

La Revista Estudios es editada por la Universidad de Costa Rica y se distribuye bajo una Licencia Creative Commons Atribución-NoComercial-CompartirIgual 3.0 Costa Rica. Para más información envíe un mensaje a 
Especial: Naturaleza amena y naturaleza agreste en las letras hispánicas

El desarraigo y la alienación pueden conducir a ser conscientes de la pérdida del oikos y, por tanto, del deterioro medioambiental. La denuncia de este último se puede observar en tres textos.

Primero, la quinta estrofa del poema "La receta", de Brenes, dice: "Y sus vasos de agua fresca.../ ¿dónde los podrá encontrar [la tierra]?/ la del río no le alcanza,/ salada está la del mar,/ lago y charco se secaron/ y la lluvia ya no está" (2008, p. 41). Estos versos y el resto del poema están apoyados por una imagen (figura 2) ubicada en el centro de las dos páginas; así, el poema queda repartido en dos columnas, una en cada página; la imagen focaliza el sentido del conjunto textual y contribuye a empatizar a los pequeños lectores con los problemas del agua y la conmemoración del 17 de Junio o Día Mundial contra la Desertificación y la Sequía.

Figura 2. llustración del poema "La receta"

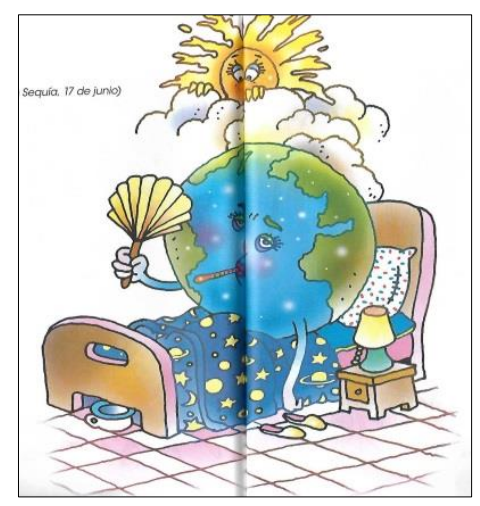

Fuente: Brenes (2008, pp. 40-41)

Este conjunto palabra-imagen - de nuevo logrado por interreferencia- ocupa un lugar privilegiado dentro del libro: desde la mitad de este no solo aborda y denuncia la incertidumbre sobre los abastecimientos, distribución y acceso del agua potable en el mundo, el calentamiento global, la desecación y la

\section{(ब) $\odot \otimes \circ$}

La Revista Estudios es editada por la Universidad de Costa Rica y se distribuye bajo una Licencia Creative Commons Atribución-NoComercial-CompartirIgual 3.0 Costa Rica. Para más información envíe un mensaje a 
Especial: Naturaleza amena y naturaleza agreste en las letras hispánicas desertificación, sino que también apela, desde los primeros años de escolaridad, a la civilización empática. Rifkin es el proponente de este concepto:

En algún punto crítico, nos daremos cuenta de que todos compartimos un planeta común, que todos somos afectados y que el sufrimiento de nuestros vecinos no es muy diferente del nuestro. En ese momento, las recriminaciones y las retribuciones servirán de poco a la hora de enfrentarnos a una crisis de proporciones tan enormes. Solamente una acción concertada que establezca un sentimiento colectivo de afiliación con la totalidad de la biosfera nos dará una oportunidad de garantizar nuestro futuro. Para ello, será necesario desarrollar una conciencia biosférica. La civilización empática comienza a emerger (2010, p. 606).

Con base en lo anterior, se puede afirmar que este y los otros poemas de Brenes mencionados, por su tratamiento de la temática del agua, invitan a los pequeños lectores -en tanto sujetos culturales de un mundo globalizado- a reflexionar hacia dentro; es decir, posibilitando su identificación y desarrollo de la empatía con el entorno a través de educativas y emotivas imágenes acuáticas (Sarlo, 2017). De esta manera, aquellos se hermanarían tanto con los demás seres humanos como con el planeta, con toda entidad (planta, animal o elemento físico) que habite el mismo espacio, y serían capaces de dar un paso más: "este salto de calidad en nuestras posibilidades empáticas [que] se hace cada vez más necesario, ya que la supervivencia de nuestro entorno depende de nuestra concienciación y de la empatía que consigamos desarrollar hacia él" (Sarlo, 2017, p. 222).

Segundo, el poema "Venecia", de Pacheco, establece irónicamente una analogía entre el hundimiento de Ciudad de México y la inmersión de Venecia en su propia lagunaxii:

Venecia es una trampa. Fue inventada por Antonio Canale II Canaletto con el único objeto de otorgarle una apariencia de verdad a sus cuadros.

\section{(C) $(00$}

La Revista Estudios es editada por la Universidad de Costa Rica y se distribuye bajo una Licencia Creative Commons Atribución-NoComercial-CompartirIgual 3.0 Costa Rica. Para más información envíe un mensaje a 
Especial: Naturaleza amena y naturaleza agreste en las letras hispánicas

Negación de Lepanto: cada piedra

es oriental / y floreció en Bizancio.

Todo lo unido tiende a separarse:

los islotes regresan a la laguna.

El agua la esculpió

y hoy la destruye.

En su agonía romántica desciende al barro original.

Perla en el lodo, joya entre muladares subacuáticos,

víctima del motor fuera de borda. (Ortega, 2009, p. 393)

Tanto Venecia como Ciudad de México fueron construidas sobre zonas lacustres por poderíos imperiales (bizantino la una, español la otra). A pesar de las obras de ingeniería que han implicado su fundación, construcción e industrialización, ambas ciudades han padecido el deterioro medioambiental hasta hoy.

Específicamente, Ciudad de México ha sufrido estragos ecológicos desde la Conquista. Si bien diferentes comunidades indígenas arcaicas y clásicas ocuparon las riberas de los lagos Zumpango, Xaltocan, Texcoco, Xochimilco y Chalco, fueron los mexicas con las fundaciones de Tenochtitlán y Tlatelolco quienes construyeron en esta área lacustre innovaciones hidráulicas como las chinampas, diques, acueductos y calzadas pro su agricultura, protección contra las inundaciones, abastecimiento y conservación de agua potable, y transporte. Sin embargo, desde 1519 se comenzaron las mayores modificaciones de estos lagos. La reconstrucción de obras de ingeniería hidráulica indoamericanas por parte de los españoles provocó el descenso y desecación de los lagos. En consecuencia, los remates de estas aguas se convirtieron en focos salobres de insalubridad y pestilencia. Ante esta amenaza, los colonizadores iniciaron el drenaje que llevó a la desaparición de dichos lagos. Tal labor se concluyó en el siglo XX con la construcción del Gran Canal del Desagüe y el Drenaje Profundo de la Ciudad de México. Debido a la crisis ambiental generada por estas obras de desviación y

La Revista Estudios es editada por la Universidad de Costa Rica y se distribuye bajo una Licencia Creative Commons Atribución-NoComercial-CompartirIgual 3.0 Costa Rica. Para más información envíe un mensaje a 
Especial: Naturaleza amena y naturaleza agreste en las letras hispánicas entubamiento de los ríos, aunada a la explosión demográfica y crecimiento de la ciudad, el Plan Texcoco busca desde 1965 rehidratar las áreas lacustres baldías, a fin de alcanzar un equilibrio ecológico e importar agua de otras cuencas.

Pese a estos esfuerzos políticos por recuperar el área lacustre de la ciudad, el poema de Pacheco expresa irónicamente la imposibilidad de este proyecto. En su lugar advierte una realidad inevitable: el hundimiento de la megápolis (ya veneciana, ya mexicana), debido a su planificación y construcción sobre el fondo barroso de aquel ecosistema primario. Durante el siglo XX, Ciudad de México se hundió 10 metros y, desde 2007 hasta 2017, un metro (Bárcena y Castañeda, 2017). La ciudad está destinada al fin catastrófico. Es como si la naturaleza buscara justicia al condenar la ciudad al cataclismo ecológico. Por medio del falseo del terreno, Gaia parece vengarse del agresor humano y su ecocidio. El poema revela la violencia lenta que se vuelve visible con el tiempoxviii. Una violencia que parece no esperó mucho tiempo para manifestarse, pues ya se presentaba en el discurso del fracaso que Pastor (1983) lee en las últimas cartas de Colón y Cortés, y la crónica de Cabeza de Vaca, cuando se describen las maneras como la naturaleza se tornaba hostil y se vengaba de los invasores.

En todo caso, la visión tanto de México como de Venecia en el poema de Pacheco es pesimista. Ambas ciudades serían sinécdoques del mundo (pos)moderno, pues todo él se encuentra en el mismo riesgo si se continúan las alteraciones de los ecosistemas con el propósito de extender las obras humanas de manera desproporcionada y sin protocolos ambientales que garanticen la evolución armónica del planeta. A este progresismo negativo alude justamente el epígrafe del poema: "Cada golpe de agua provocado por los/ motores hunde un poco más a Venecia". El poema de Pacheco, por tanto, es una analogía de la caída del antropocentrismo (pos)moderno que ha sido responsable del abuso, violencia y alteración de la biosfera.

\section{(๑) $\odot \odot$}

La Revista Estudios es editada por la Universidad de Costa Rica y se distribuye bajo una Licencia Creative Commons Atribución-NoComercial-CompartirIgual 3.0 Costa Rica. Para más información envíe un mensaje a revistaestudios.eeg@ucr.ac.cr. 
Especial: Naturaleza amena y naturaleza agreste en las letras hispánicas

Tercero, en el poema "Pez en el agua", de Vitale, se representa una idea de lo infinito. Forns-Broggi (2012) señala que este poema propone pensar lo infinito desde la pérdida, ya que lo infinito se representa por medio de un pez en un lago infinito que es un lugar imaginario donde la laceración del agua se dirige a su desaparición. Sin embargo, ¿propone realmente este poema lo infinito como parte de una ecuación de la extinción?

Inicialmente, se enuncia a un pez cómodamente situado en su hábitat natural. Acto seguido, el sujeto lírico advierte que se trata de un pez pensado por el filósofo y matemático alemán Gottfried Leibniz. A partir de este indicio temático, el poema comienza a desarrollar la idea del cálculo infinitesimal, una de las invenciones de Leibniz. ¿De qué manera se representa esta en el poema? De forma concreta (similar al poema de Chirinos), mediante un retruécano, versos partidos mediante juegos de sangrados en escalerilla y un paralelismo que trazan, tanto gráfica como estilísticamente, la infinita interconexión e interdependencia de lo microcósmico en lo macrocósmico y viceversa, de modo que son uno mismo. Así, se rompe la dicotomía moderna de que existen por separado lo exterior y lo interior. Esta continuidad infinita del pez en el lago y viceversa, por tanto, ilustra el tejido cósmico a manera de la banda de Möbius, cuya propiedad matemática es la de ser un solo objeto.

Sin embargo, a partir del séptimo verso, se sugiere otro valor: ese lago infinito no se encuentra en este mundo sino en otro utópico, porque los lagos de este están lastimados, heridos, devastados. Este poema, pues, termina cuestionando la utopía tan presente en la literatura hispánica y se enfrenta al desencanto causado por los procesos (pos)modernos de industrialización y urbanización acelerados. En este sentido, se puede afirmar que dicho poema manifiesta un tono irónico y, a la vez, elegíaco ante la contaminación del agua y la destrucción de lagos y lagunas en el presente.

\section{(๑) $\odot \odot$}

La Revista Estudios es editada por la Universidad de Costa Rica y se distribuye bajo una Licencia Creative Commons Atribución-NoComercial-CompartirIgual 3.0 Costa Rica. Para más información envíe un mensaje a revistaestudios.eeg@ucr.ac.cr. 
Especial: Naturaleza amena y naturaleza agreste en las letras hispánicas

Al final, el pez-el lago, lo infinito, sí entran en el poema en la ecuación de la extinción, porque aquello que se pensaba ilimitado; es decir, el agua, un recurso que se creyó inagotable durante tanto tiempo, ahora ha girado hacia el extremo de su desaparición. Aun así, el poema de Vitale no se queda en el pesimismo suscitado por el mito del apocalipsis. El pesimismo da forma a una utopía que busca la armonía y la continuidad en el cambio sin excluir la conciencia del dolor y la injusticia ecológica, para así demandar la generación de soluciones sociales, económicas, políticas y culturales interesadas en resguardar los ecosistemas e integradas en un todo. Lo mismo podría interpretarse, mutatis mutandis, en el anterior poema de Pacheco. En fin, dice el poema de Vitale:

Como pez en el agua, como pez, empero, pensado por Leibniz:

pez lleno de lago, de lago lleno de peces, pez infinito lleno de lagos infinitos, a la orilla de un sí mismo infinito.

Entonces sí, de un lago como pez en el agua de otro mundo donde

no

nos laceren lagunas. (1998, p. 55)

El tema del deterioro medioambiental poco a poco ha conducido a hablar sobre el mito del apocalipsis. Este, desde el hito de las bombas atómicas de Hiroshima y Nagasaki, se ha presentado significativamente en la ecopoesía hispánica en torno a la progresiva destrucción ecológica del planeta (Binns, 2004). No se entiende apocalipsis en sentido religioso, sino histórico "en referencia a los acontecimientos recientes de orden nuclear, bélico, ecológico, demográfico" (Parkinson Zamora, 1994, p. 11). Tal mito se puede identificar en dos poemas.

\section{(c) $)(1)(2)$}

La Revista Estudios es editada por la Universidad de Costa Rica y se distribuye bajo una Licencia Creative Commons Atribución-NoComercial-CompartirIgual 3.0 Costa Rica. Para más información envíe un mensaje a 
Especial: Naturaleza amena y naturaleza agreste en las letras hispánicas

Por un lado, en "Alas del sur" (1982), de Bartolomé, se poetiza el incendio apocalíptico de una selva. En medio de esta catástrofe, los seres bióticos y abióticos padecen el delirio y la angustia de su aniquilamiento y devastación ${ }^{\mathrm{xix}}$. Ejemplos de ello son los del pantano y el cocodrilo o el caimán. Para Forns-Broggi (2012), tanto como el humedal, el pantano también es análogo del lago. Se observa en los siguientes versos cómo este depósito de agua sufre el hervimiento y desecación; mientras que los reptiles, intentando refugiarse en su propio hábitat, padecen su dramática cocción, asfixia y muerte: "Y el pantano más grande se secó/ Y el cocodrilo se coció/ Y la tersa superficie de la laguna hirvió/ Y el pequeño caimán se deshidrató" (s.f.: §38).

Por otro lado, en "Suburbia", de Cotter, se expone el mito del apocalipsis a través de una topografía en donde se describen restos de la humanidad y un ambiente urbano calcinado por la destrucción atómica. En este espacio asolado por la lluvia ácida, los pocos principios de vida (insectos sobre todo; mientras alondras, cuervos y buitres consumen carne descompuesta) padecen alucinaciones o bien son testigos de la paulatina corrosión de los edificios, los ríos, el aire. El día revela en toda su extensión el caos. Y el lago es parte de este escenario: "El fuego en el lago marcha/ como el invierno/ sobre las huellas fosforescentes/ de la soledad" (1987, p. 25).

En ambos poemas, pues, el mito del apocalipsis adquiere su representación visual en la imagen del fuego sobre el agua lacustre, en tanto la combustión connota el caos, el peligro inminente, la desesperación y el exterminio de los mundos humano y más-que-humano.

Este mito ha conducido a hablar sobre conciencia y discurso tóxicos. Deitering propone el concepto conciencia tóxica para referirse a la presencia de la contaminación y los restos perjudiciales en la literatura, debido al "cambio desde una cultura definida por su producción hacia una cultura definida por sus desechos" (1996, p. 196). La presencia de esta conciencia en el texto literario

\section{(c) (i) (2)}

La Revista Estudios es editada por la Universidad de Costa Rica y se distribuye bajo una Licencia Creative Commons Atribución-NoComercial-CompartirIgual 3.0 Costa Rica. Para más información envíe un mensaje a revistaestudios.eeg@ucr.ac.cr. 
Especial: Naturaleza amena y naturaleza agreste en las letras hispánicas permite clasificarlo como un discurso tóxico, pues aborda la acción humana como nociva para el entorno. Obsérvense a continuación cuatro ejemplos de discursos tóxicos.

Primero, el poema "Lago Ontario", de Pacheco, presenta una unidad temática inicial donde se describe, con un tono impresionista, inclusive modernista, la intemporalidad de un ecosistema lacustre vivo y resplandeciente. Sin embargo, de inmediato se presenta una unidad temática de contraste, donde se pasa desde el locus amoenus y el lirismo hasta el ecosistema condenado y realismo sucio: "Todo es azul mientras lo navegamos/ todo belleza y calma/ Hasta que al acercarnos a la ciudad/ surgen las manchas pardas casi negruzcas/y los áisbergs [sic] de espuma sucia/ de los letales detergentes" (1986, p. 174). A propósito, obsérvese cómo esta prosopografía del agua contrasta radicalmente con el azul metálico y la transparencia de los lagos en los poemas de Volkow y Calderón.

Volviendo, de acuerdo con Binns (2004), el tránsito desde el locus amoenus y el lirismo hacia el realismo sucio mina e invalida símbolos poéticos que tradicionalmente se han pensado invariables; verbigracia: los lagos; o inclusive la alondra, que en el poema de Cotter pierde todo su simbolismo de alegría, luminosidad, transparencia y hierogamia (Chevalier y Gheerbrant, 1988) para representar la muerte e inmundicia como cualquier otra ave carroñera. Los lagos biológicamente están muriendo o han muerto ya. De ahí que el símbolo lago ya no sirva como antes para connotar pureza. Los lagos y lagunas connotarían ahora la realidad contaminada y contaminante. Así pues, el sujeto lírico se desprende del lirismo esplendoroso y la imaginería anacrónica para representar, irónicamente, al menor de los cinco Grandes lagos de América del Norte. Su ironía lo lleva a desprenderse de modelos retóricos, estilísticos y simbólicos que ante el apocalipsis resultan insostenibles.

Segundo, se ha analizado arriba cómo la laguna en el poema de Albán aparece personificada como un ente de doble naturaleza (sagrada y profana) que, en su 
Especial: Naturaleza amena y naturaleza agreste en las letras hispánicas proceso de perfeccionamiento místico, desciende en forma de lluvia a este mundo. Pues bien, su proceso de inserción en el ámbito terrenal comienza al recibir a los hombres, los seres profanos quienes llegan a mezclarse con su agua y divertirse en ella:

Luego llega la vida con su traje de niño

y la rodea de ángeles dispuestos a crecer ante el primer olvido, y la rodea de besos de quince años, y a la pobre laguna que estaba hecha de cielo, el mundo le cae encima:

gritos, botellas y náuseas imprevistas

mancillan su horizonte

de espejo enamorado de la luna.

Y cómo se estremece la laguna manchada por la vida.

Ella que se hizo cielo y el cielo se hizo ella, ahora yace desnuda y violada por todas las risas de los niños de este mundo. (2010, p. 262)

Estas estrofas componen una escena donde el mundo desacralizado invade este centro sagrado y cósmico. A la laguna llegan seres en quienes, desde pequeños, la conducta racional y antropocéntrica predomina sobre su facultad intuitiva y conciencia ecológica. A ellos únicamente les interesa bañarse y jugar en la laguna, sin importarles mancillarla, pues vierten en ella desechos sólidos, orgánicos, inclusive psicológicos y sentimentales; en fin, productos contingentes de una realidad desacralizada. En consecuencia, la laguna se convierte en una mancha: han intoxicado su carácter ilímite e indefinido de ser Conocimiento y Verdad cósmica. El sujeto lírico insiste en describirla harta, fastidiada, acongojada por tanto desecho que la invade; la retrata víctima de los seres profanos.

Campos (2012) ha interpretado esta mancilla como parte del tránsito individual de la laguna hacia su perfección mística, pues ella debe mancharse de humanidad cotidiana para llegar a pertenecer al plano de lo numinoso. Según afirma

\section{(c) (1) (-)}

La Revista Estudios es editada por la Universidad de Costa Rica y se distribuye bajo una Licencia Creative Commons Atribución-NoComercial-CompartirIgual 3.0 Costa Rica. Para más información envíe un mensaje a 
Especial: Naturaleza amena y naturaleza agreste en las letras hispánicas

Chinchilla: "lo sagrado es tanto sagrado como manchado o mancillado" (2010, p. 107). Sin embargo, tal mancilla se puede interpretar asimismo como los restos culturales y materiales tóxicos de una humanidad que, sin conciencia ecológica ni religiosa ${ }^{\mathrm{x}}$, se extiende, invade y viola la biosfera mediante la hiperurbanización e hipercontaminación actuales.

Tercero, el sentido de arraigo lleva al sujeto lírico de Oráculo sobre Managua, de Cardenal, a preocuparse por la degradación del lago Xolotlán. Aquel, en un principio, se acerca a una zona periférica al norte de Managua y construye una topografía del lugar. No se limita solo a mencionar las lagunas pluviales Asasosca (reserva de agua potable de la ciudad), Nejapa y Tiscapa como parte de la llanura volcánica de los grandes lagos en el centro de Nicaragua, sino que, a modo de arqueólogo poético, rescata las huellas culturales de los pueblos arcaicos que habitaron el ecosistema de Acahualinca en el Holocenoxxi:

Detrás de la fábrica de Hilados y Tejidos (si ha quedado la fábrica tras el terremoto) y junto al cauce de desagüe, cerca del lago, entre basuras, bacinillas rotas, están o estaban las huellas, impresas en estrato volcánico.

Tal vez sin tejido textil, y ni siquiera cerámica, ocuparon esta área de Managua junto con el bisonte.

Vivían de la caza y la pesca y la recolección de alimentos.

Tiscapa, Asososca, Nejapa

las lagunas actuales eran un solo volcán humeante y una vez cayó ceniza como una nieve negra y quedaron las huellas en la corriente de lodo volcánico que iba hacia el lago y bajo la ceniza se solidificaba: huellas de gente en una misma dirección —hacia el lagohuellas huyendo del volcán (1975, p. 21)

La topografía y labor arqueológica poéticas atestiguan y denuncian asimismo los restos contaminantes, productos de un modelo industrial y consumista neoliberal, que llegan hasta el lago e inclusive se superponen a las huellas de Acahualinca: "con la primera cerámica. Maya. Monocroma. De Nicoya/ (polícroma). De la época de Cristo. Cerámica Luna/ (lacas blancas y motivos de líneas finas). Monos/

La Revista Estudios es editada por la Universidad de Costa Rica y se distribuye bajo una Licencia Creative Commons Atribución-NoComercial-CompartirIgual 3.0 Costa Rica. Para más información envíe un mensaje a 
Especial: Naturaleza amena y naturaleza agreste en las letras hispánicas jaguares rojos con fondo blanco, incensarios. Y encima/ trozos de Coca Colas y llantas Goodyear y bacinillas" (Cardenal, 1975, p. 22). De esta forma, los restos tóxicos de un presente degradado se yuxtaponen a los restos de las culturas que antes poblaron dicho lugar (Binns, 2004). Quizá esta yuxtaposición pretenda, como en el poema de Pacheco, una analogía para señalar irónicamente el exterminio a que está propensa la sociedad capitalista, no debido a causas naturales, sino a su catastrófico desequilibrio. De ahí que el sujeto lírico se valga de la deixis para señalar el sitio preciso, dirigir al lector y evidenciarle: 1) la fetidez de los suburbios; 2) la pobreza de la infancia; 3) la degeneración del hábitat donde idílicamente las nuevas generaciones habrían crecido, pero que, en realidad, es un espacio mancillado $y$, entre moscas y zopilotes, condenado a muerte por el neoliberalismo y la guerra; 4) la miseria que, como dice Binns (2004), escandaliza porque representa la modernidad omnipresente que intoxica el lago:

Allí acaban las cloacas.

En la costa del lago los niños juegan haciendo hoyitos con un palito a quién saca más moscas de su hoyito En el agua algodones, papel de inodoro, algún condón. Cerca el rastro. Sobre sus desperdicios zopilotes. Un arroyo de aguas-negras lechosas fluye hacia el lago a la derecha la envenenada laguna de Acahualinca verde-tierno... chozas en la llanura donde los camiones de D.N. descargan (o descargaban) la basura de Managua llanura de latas papeles plástico vidrio esqueletos de autos zopilotes en palos secos esperando más camiones

Allí desembocan otras cloacas sin llegar al lago (la luna riela sobre la mierda) (1975, pp. 22-23)

Por cierto, esta presencia de las moscas recuerda intertextualmente el discurso tóxico de El canto de las moscas (1997), de la colombiana María Mercedes Carranza. En su poemario, se muestra un paisaje rural envenenado igualmente por la guerra, en donde se atestigua el exterminio humano y ecológico.

\section{(c) (i) (9) (2)}

La Revista Estudios es editada por la Universidad de Costa Rica y se distribuye bajo una Licencia Creative Commons Atribución-NoComercial-CompartirIgual 3.0 Costa Rica. Para más información envíe un mensaje a 
Especial: Naturaleza amena y naturaleza agreste en las letras hispánicas

Regresando al poema de Cardenal, el epíteto "verde-tierno" describe irónica y atrozmente el lago, ya que entremezcla, como en las mismas aguas, lo verde natural que aún queda y lo verde rancio que vía los desagües cae en el mismo lago que ayer abasteció, albergó y refugió a los pobladores indoamericanos autóctonos y su desarrollo cultural, pero que para la década de los 70 sirve de vertedero de las víctimas de un sistema político injusto.

En fin, en torno al lago Xolotlán se articulan el mito del paraíso perdido, en su rescate de lo indígena y visión armónica del cosmos; pero también, como observa Binns (2004), la bajada al infierno: "Lentamente la corriente en dirección al lago/ la corriente de mierda de Managua/ y en ella huellas de pies desnudos/ como los de aquellos que por allí fueron huyendo/ a $10 \mathrm{mts}$. de profundidad como si fuera ahora en lodo fresco" (Cardenal, 1975, p. 25). Este lago se convierte, pues, en el ejemplo vivo de la crisis apocalíptica contemporánea.

Cuarto, en el poema "Nueva ecología", también de Cardenal, el sujeto lírico atribuye no solo la contaminación del lago Xolotlán, sino la general degradación ecológica de Nicaragua a la dictadura somocista. La codicia e insensibilidad de los Somoza figuran como las culpables de la explotación, venta y deterioro del medio ambiente nacional. De ahí que, entre los muchos daños, señale el impacto sobre hábitat lacustres: "Los somocistas también destruían los lagos, ríos, y montañas./ [...] La laguna de Moyuá se había secado. Un coronel somocista/ robó las tierras de los campesinos y construyó una represa./ La laguna de Moyuá que por siglos estuvo bella en ese sitio" (Remacha, 1990, p. 117).

El entusiasmo revolucionario y ecologista del sujeto lírico, no obstante, predice la recuperación de una armonía no solo social, sino también ecológica gracias al régimen sandinista (Binns, 2004). Por eso, proclama: "Recuperaremos los bosques, ríos, lagunas./ Vamos a descontaminar el lago de Managua" (Cardenal, 1990, p. 118). Estas son profecías que desde el título del poemario anterior, Oráculo sobre Managua ${ }^{x x i i}$, el sujeto lírico se dejaba pronunciar, porque sus 
Especial: Naturaleza amena y naturaleza agreste en las letras hispánicas ecopoemas son oráculos, profecías esperanzadoras de la regeneración de Nicaragua, merced a la revolución socialista y la teología de la liberación que, por extensión, también afectarían positivamente la (r)evolución ecológica nacional y regional. Estas proclamas llevan a personificar a los lagos porque ellos, al ser parte de la biosfera nicaragüense, también viven eufóricos el triunfo de la revolución sandinista. De ahí que esta última sea considerada por el sujeto lírico una revolución doble: tanto los seres humanos como el mundo-más-que-humano ganan: "La liberación no sólo la ansiaban los humanos./ Toda la ecología gemía. La revolución/ es también de los lagos, ríos, árboles, animales" (Cardenal, 1990, p. 118).

El sentido de arraigo lleva a Cardenal, en definitiva, a representar en su poesía tanto las conciencias tóxicas ecológica y social de Nicaragua; así como los deseos y esfuerzos sostenibles de volver a habitar y ser parte de (eco)sistemas que beneficien, por partida doble, la biosfera.

Empero, no siempre se alcanzan dichos (eco)sistemas. Por eso, estos discursos tóxicos pueden conducir a la experiencia del vómito. El contenido tóxico, que se vuelve insoportablemente perjudicial para los organismos, es expulsado con la misma violencia con que ingresó en sus cuerpos. La transgresión y destrucción de la biosfera, así como el irrespeto por las vidas, se traducen en un gesto nauseabundo: un desencanto, una reprobación, una repugnancia por la racionalidad, el mercantilismo, la globalización, el imperialismo ecológico (adelante se explicará este concepto)... El vómito no es sino una náusea existencial, ética, medioambiental e histórica ante la voraginosa insostenibilidad de los (eco)sistemas (pos)modernos. El vómito surge del choque contra el antropocentrismo y el egocentrismo. Al respecto, dos poemas.

Por una parte, en "Me declaro" (2010), de Puglisi, el sujeto lírico, como representante de la humanidad, reconoce la culpabilidad del especismo en la devastación del medio ambiente y su biota. Sobre el ecosistema lacustre, por

\section{(C) $(0 \bigcirc)$}

La Revista Estudios es editada por la Universidad de Costa Rica y se distribuye bajo una Licencia Creative Commons Atribución-NoComercial-CompartirIgual 3.0 Costa Rica. Para más información envíe un mensaje a 
Especial: Naturaleza amena y naturaleza agreste en las letras hispánicas ejemplo, se va atestiguando cada vez más la cantidad de cadáveres de animales desesperados por sobrevivir, intoxicados, mutilados. Este desfile sobre el agua no solo remarca el paso del tiempo con rumbo hacia la inevitable muerte del planeta, sino también las pocas posibilidades que quedan ya para revertir todo acto de violencia contra la biosfera: "Me declaro culpable/ [...] del lago que arroja en vómitos intensos/ los cuerpos tristes de animales ahogados/ en el propio cultivo de una destrucción ya sin sentido,/ (esqueletos apenas de frutos que caen/ de las altas copas secas de magnolias aturdidas)/ de los fósiles futuros que permanecerán siempre en silencio" (2011: §2).

Por otra parte, en "Vómito", de Galeano, se ejemplifica la barbarie ecológica en la Amazonía: la angustia y el malestar que implican la tala de la selva, la contaminación del agua, la caza de especies animales y el exterminio de sociedades y culturas indígenas. Esta denuncia de la anulación y aniquilamiento de pueblos indoamericanos es un tema recurrente en la ecopoesía más que todo hispanoamericana del Cono Sur; por ejemplo: en De la tierra sin fuegos (1986), del chileno Juan Pablo Riveros. Si bien Forns-Broggi (1998) señala que en este apenas citado poemario de Riveros se presenta el don del reparo, es posible extender dicha presencia a "Vómito". En este poema de Galeano, es tal la devastación producida por la sobreexplotación y la violencia de las grandes potencias industriales contra el Tercer Mundo, que, como lo indica el mismo título del texto, esta se apodera de la biosfera regional y global, y se traduce en un inevitable vómito catastrófico. Irónicamente, una voz indefinida apenas acota que algo le ocurre a la tierra, y luego se desentiende del asunto. Al final, el sujeto lírico plantea mordazmente que los pueblos indígenas y sus culturas, o lo que resta de ellas, están sentenciados ineluctablemente a un tránsito hacia la desaparición: "Muchos indios no pueden dormir la pesadilla./ Los lagos y los ríos vomitan animales, árboles y gente./ 'Algo debió caerles mal a los ríos y a los lagos', dijo

\section{(C) $(000$}

La Revista Estudios es editada por la Universidad de Costa Rica y se distribuye bajo una Licencia Creative Commons Atribución-NoComercial-CompartirIgual 3.0 Costa Rica. Para más información envíe un mensaje a revistaestudios.eeg@ucr.ac.cr. 
Especial: Naturaleza amena y naturaleza agreste en las letras hispánicas alguien./ El vómito cubre la tierra y se expande por el universo./ Es bueno que los indios construyan sus casas con la forma de las barcas" (2003, p. 20).

El tema del exterminio de los pueblos autóctonos americanos suele conducir por asociación a la reflexión sobre el imperialismo ecológico. Este concepto, propuesto por Crosby (1988), abarca las acciones de dominación de los pueblos colonizadores: la mercantilización de la naturaleza, el expolio, el saqueo sistemático de bienes comunes y la imposición de una visión de mundo que introducen al ser humano y la naturaleza en una relación utilitarista y depredadora. Como dice Crosby, el triunfo de los europeos en América y otras latitudes no se debió únicamente a la superioridad de su armamento, sino también a la afectación que provocaron en lo ecológico.

Desde el inicio, la Conquista de América, por ejemplo, supuso cambios en la naturaleza, pues aquella significó una lucha para vencer tanto al indígena como al ecosistema que lo sostenía (Binns, 2004). Antes se ha mencionado que a partir de 1519 Tenochtitlán comenzó a sufrir modificaciones en sus estructuras sociocultural, política y lacustre. Tales alteraciones respondieron a la dicotomía moderna civilización / barbarie y al consecuente enfrentamiento de cosmovisiones: el antropocentrismo anti-natural contra el geocentrismo que llevaba a los indoamericanos a concebir el cosmos "como un gran organismo, en el cual [ellos] no eran protagonistas centrales sino una simple parte integral e inseparable del ecosistema" (Binns, 2004, p. 86). Por consiguiente, se creó y legitimó no solo un sistema exterminador del ecosistema americano, sino también lo que en este artículo se propone denominar signos de alienación. Por su drenaje y desecación, el lago de Texcoco constituye uno de estos signos porque, si se parte de que los indígenas estaban integrados en su entorno, vivían su ecocentrismo, entonces, la degradación y destrucción ecológica de dicho lago significaría asimismo la represión y derrota inevitable del pueblo mexica y su (eco)sistema mítico, social, político y cósmico. Este signo de alienación, en definitiva, se poetiza y plantea de

\section{(C) $(\Theta \odot \odot$}

La Revista Estudios es editada por la Universidad de Costa Rica y se distribuye bajo una Licencia Creative Commons Atribución-NoComercial-CompartirIgual 3.0 Costa Rica. Para más información envíe un mensaje a revistaestudios.eeg@ucr.ac.cr. 
Especial: Naturaleza amena y naturaleza agreste en las letras hispánicas forma ejemplar en las primeras tres estrofas de "Poema de amor en la Ciudad de México", de Aridjis:

En este valle rodeado de montañas había un lago, y en medio del lago una ciudad, donde un águila desgarraba a una serpiente sobre una planta espinosa de la tierra.

Una mañana llegaron hombres barbados a caballo y arrasaron los templos de los dioses, los palacios, los muros, los panteones, y cegaron las acequias y las fuentes.

Sobre sus ruinas, con sus mismas piedras, los vencidos construyeron las casas de los vencedores, erigieron las iglesias de su Dios, y las calles por las que corrieron los días hacia su olvido. (White, 2014, p. 42)

\section{CONCLUSIONES}

El estudio panorámico realizado con motivo de los lagos y lagunas permite no solo demostrar la riqueza y variedad formales e ideológicas de la ecopoesía hispánica, sino también establecer dentro de esta al menos once principios funcionales en que el desarrollo poético de aquellos dos motivos tiende a asentarse. Así, se puede afirmar que los lagos y lagunas figuran como:

1) Paisajes ecocéntricos que, allende el paisaje antropocéntrico (fragmento principal o secundario de una topografía, estampa, adorno, psicogeografía, concepto) o en tensión con este, I) presentan a los lagos y lagunas como accidentes fluviales y reconocen su valor geomorfológico; II) desarrollan e inscriben una topofilia o una preocupación ecológica.

\section{(c) (i) (2)}

La Revista Estudios es editada por la Universidad de Costa Rica y se distribuye bajo una Licencia Creative Commons Atribución-NoComercial-CompartirIgual 3.0 Costa Rica. Para más información envíe un mensaje a 
Especial: Naturaleza amena y naturaleza agreste en las letras hispánicas

2) Espacios vivos que revelan su biodiversidad, así como las interconexiones e interdependencias ecológicas, al mismo tiempo que bioalfabetizan al lector, apelándolo al rescate, conservación y cuidado de estas zonas bióticas.

3) Geopsiques, que permiten reconocer al lago o la laguna como un organismo viviente y estrechar con él una afiliación topofílica, biofílica o etnozoológica.

4) Personificaciones o entes animados que: I) advierten la presencia del mito del anima mundi, desde una perspectiva deísta, panteísta o simbólica; II) implican una visión orientada a borrar las fronteras y jerarquías entre el ser humano y el mundo-más-que-humano; III) ubican a estos dos últimos en un mismo nivel de valor, coexistencia y sentido en la biosfera; IV) diluyen las dicotomías modernas de civilización / barbarie, cultura / naturaleza.

5) Formas cósmicas de la red universal, las cuales: I) conjugan lo mítico y lo sagrado de la naturaleza; II) le revelan al ser humano su homologación e indistinción respecto del resto de la naturaleza; III) conducen hacia la ecoespiritualidad en términos de sintonía y unidad armoniosa, es decir, la religación cósmica ante la crisis ecológica.

6) Elementos constitutivos del cuerpo femenino en tanto materia primordial y continuidad del cosmos, acorde con una propuesta ecofeminista que ofrece un nuevo paradigma estructural y ético antinaturista: una valoración del cuerpo y ser femeninos frente al patriarcado naturalizado.

7) Oikos y organismos perdidos por causa del ecocidio promovido por el especismo, antropocentrismo y egocentrismo. En esta coyuntura, el deterioro medioambiental lacustre y el cataclismo ecológico en general permiten I) abordar principalmente los problemas del agua en el nivel regional y mundial, así como las consecuencias del cambio climático; II) 
Especial: Naturaleza amena y naturaleza agreste en las letras hispánicas demostrar y denunciar el abuso, violencia y alteración de la biosfera; III) representar por medio de analogías y ecuaciones ecológicas la caída del antropocentrismo (pos)moderno y la destrucción del planeta; IV) enunciar la utopía, el desencanto, la conciencia del dolor y la injusticia ecológica, pues la articulación de los cuatro no solo evidencia la degradación de la biosfera, sino que también, valiéndose de la perspectiva holística de la ecopoesía, invita simultáneamente a la búsqueda de soluciones sostenibles.

8) Plasmaciones del mito del apocalipsis y el cataclismo, principalmente a través de la imagen visual de la combustión sobre el agua.

9) Catalizadores de la conciencia tóxica ecológica y social ya que: I) patentizan la mancilla provocada por los desechos culturales y materiales de la hiperurbanización e hipercontaminación, así como por el imperialismo ecológico de las potencias mundiales sobre el Tercer Mundo; II) obligan, al mismo ritmo del deterioro medioambiental, a conformar nuevos discursos poéticos en los que se modifican la poesía y su visión, se ironiza la esencia y función literarias de esta; así como se replantean los modelos retóricos, estilísticos y simbólicos, pretendiendo que sean coherentes y afines a la degradación ecológica.

10) Canalizadores del vómito violento de la biosfera, generado por el antropocentrismo, egocentrismo, especismo y la creciente insosteniblidad de los (eco)sistemas (pos)modernos.

11) Signos de alienación dentro de un discurso poscolonial, dado que la devastación de los ecosistemas ocupados por los indoamericanos significa al mismo tiempo la represión y derrota de sus pueblos.

En suma, el análisis textual no solo permitió definir y proponer estos once principios funcionales, sino que también deja ver que, desde su forma y contenido, la ecopoesía hispánica contemporánea remite a la integridad de otros textos 
Especial: Naturaleza amena y naturaleza agreste en las letras hispánicas (literarios y culturales), otras criaturas y estructuras del mundo, porque ella proviene de una conciencia ecológica que busca, como dijera Ruecker (1996), convertirse en una forma de acceso al imaginario social, con el propósito de fisurar y desestabilizar la racionalidad moderna. De cierto modo, aquellos once principios funcionales ratificarían el aserto de Forns-Broggi (2012) de que el ecopoema hispánico puede ser concebido como un campo generador de energías, porque transforma la relación actual de los seres humanos con la naturaleza, ya al criticar la alienación con respecto a lo natural; ya al cuestionar los hábitos colectivos, los valores de relación ambiental determinados por la herencia colonial y la posibilidad de nutrir un saber ecologista que siente las bases del diálogo transcultural y las políticas de sustentabilidad.

El análisis, asimismo, comprueba la validez de la ecocrítica al entablar constructivamente "una conexión entre la naturaleza y la literatura con el fin de criticar lo destructivo, lo poco ético y lo instrumentalista, por una parte; y celebrar y promover lo constructivo, la ética medioambiental y lo ecológico, por otra" (Murphy, 2010, p. 13). Una vez más, los estudios ecocríticos y sus instrumentos conceptuales transdisciplinarios contribuyen, como afirman Flys Junquera, Marrero Hernández y Barella Vigal (2010), con la sensibilización y cambio de actitudes con respecto a todas las moradas actuales y las especies que habitan en ellas.

Los motivos de los lagos y las lagunas a lo largo de la ecopoesía hispánica contemporánea conducen a los lectores a ser parte de una civilización empática; invitan a trascender —aplicando las palabras de White (2014, p. 12) - "las fronteras nacionales para describir experiencias generales sobre las cuales los bio-ciudadanos de todos los países del mundo deberían reflexionar". Esta reflexión a que cada quien debiera someterse tendría que centrarse, según sugiere Sarlo (2017), en cuestionarse personalmente sobre su participación directa en la conservación de las aguas y el derecho de todo ser humano a tener acceso a ella,

\section{(C) $(\Theta \odot \odot$}

La Revista Estudios es editada por la Universidad de Costa Rica y se distribuye bajo una Licencia Creative Commons Atribución-NoComercial-CompartirIgual 3.0 Costa Rica. Para más información envíe un mensaje a 
Especial: Naturaleza amena y naturaleza agreste en las letras hispánicas

ya que, como sentencia Virilio (2003), el Gran Accidente ecoescatológico integra globalmente a la humanidad y terminará desintegrándola físicamente por igual.

\section{REFERENCIAS BIBLIOGRÁFICAS}

Abram, D. (1997). The Spell of the Sensuous: Perception and Language in a MoreThan-Human World. Nueva York: Vintage.

Albán, L. (2010). Enciclopedia de maravillas. Tomos IV. Pittsburg, Estados Unidos: International Poetry Forum.

Araújo, J. (1997). ¿Brota el árbol seco? De lo ecológico como pensamiento. Revista de Occidente, 194-195,143-160.

Barbas-Rhoden, L. (2014). Hacia una ecocrítica transnacional: Aportes de la filosofía y crítica cultural latinoamericanas a la práctica ecocrítica. Revista de Crítica Literaria Latinoamericana, 79 (1), 79-96.

Bárcena, M. y Castañeda, J. (2017). Hundimiento de la ciudad de México alcanzó un metro en 10 años. [http://www.foroambiental.com.mx/hundimiento-de-laciudad-de-mexico-alcanzo-un-metro-en-10-anos/].

Barella Vigal, J. (2010). Naturaleza y paisaje en la literatura española. En Flys Junquera, C., Marrero Henríquez, J. y Barella Vigal, J. (eds.). Ecocríticas. Literatura y medio ambiente. 219-238. Madrid / Frankfurt / Orlando: Iberoamericana-Vervuert.

Bartolomé, E. (s.f.). Ala del sur. [https://www.palabravirtual.com/index.php?ir=ver voz1.php\&wid=498\&t=Ala+ del+sur \&p=Efra\%EDn+Bartolom\%E9\&o=Efra\%EDn+Bartolom\%E9]

Belli, G. (1997). Apogeo. Managua: Anamá.

-----. (2003). Mi íntima multitud. Madrid: Visor.

Binns, N. (2004). ¿Callejón sin salida? La crisis ecológica en la poesía hispanoamericana. Zaragoza: Prensas universitarias de Zaragoza.

\section{(c) (i) (2)}

La Revista Estudios es editada por la Universidad de Costa Rica y se distribuye bajo una Licencia Creative Commons Atribución-NoComercial-CompartirIgual 3.0 Costa Rica. Para más información envíe un mensaje a revistaestudios.eeg@ucr.ac.cr. 
Especial: Naturaleza amena y naturaleza agreste en las letras hispánicas

Boff, L. (1996). Ecología: grito de la tierra, grito de los pobres. Madrid: Trotta.

Brenes, A. (2008). Bienaventuranzas de la naturaleza. San José: EUNED.

Buell, L. (1995). The Environmental Imagination: Thoreau, Nature Writing and the Formation of American Culture. Cambridge: The Belknap Press.

----. (1999). The ecocritical Insurgency. New Literary History, 30, 699-712.

----. (2001). Writing for an Endangered World: Literature, Culture, and Environment in the U.S. and Beyond. Cambridge / Londres: The Belknap Press of Harvard University Press.

Campos, J. (2008). El poeta en llamas. San José: Editorial Lunes.

Campos, R. (2012). De la permanencia de lo sagrado en la Enciclopedia de maravillas de Laureano Albán. Tesis de maestría. Universidad de Costa Rica.

----. (2017). Abriendo espacios desde el margen: Los estudios sobre la ecopoesía hispánica contemporánea. En VII Congreso Internacional de BETA Asociación de Jóvenes Doctores en Hispanismo: Canon y Margen en las Culturas y Literaturas Hispánicas. Santander, Universidad de Cantabria y CIESE-Comillas.

Cardenal, E. (1975). Oráculo sobre Managua. s.l.: Agermanament.

Chen, J. (2015). Conciencia ecocrítica en la poesía nicaragüense contemporánea:

Alberto Juárez Vivas y Henry A. Petrie. Káñina, 39 (1), 99-106.

Chinchilla, K. (2010). Conociendo la mitología. San José: EUCR.

Chirinos, E. (2001). Breve historia de la música. Madrid: Visor.

Cisneros Cox, A. (1997). Naturaleza y brevedad: el haiku en la poesía latinoamericana. Evohé, 3, 127-152.

Cotter, P. (1987). Suburbia. San José: Imprenta Nacional.

Crosby, A. (1988). Imperialismo ecológico: la expansión biológica de Europa, 9001900. Barcelona: Grijalbo.

Cuadra, P. (2003). Poesía II. Managua: Fundación Vida.

\section{(c) (i) (2)}

La Revista Estudios es editada por la Universidad de Costa Rica y se distribuye bajo una Licencia Creative Commons Atribución-NoComercial-CompartirIgual 3.0 Costa Rica. Para más información envíe un mensaje a revistaestudios.eeg@ucr.ac.cr. 
Especial: Naturaleza amena y naturaleza agreste en las letras hispánicas

Deitering, Cynthia. (1996). The Postnatural Novel: Toxic Consciousness in Fiction of the 1980s. En Glotfelty, C. y Fromm, H. (eds.). The Ecocriticism Reader: Landmark in Literary Ecology. 196-203. Athens / Londres: University of Georgia Press.

Dobles, J. (1997). Costa Rica poema a poema: un recorrido por el alma secreta de la patria. San José: EUNED.

Donoso, A. (2015). Estudios literarios ecocríticos, transdisciplinaridad y literatura chilena. Acta Literaria, 51, 103-118.

Durand, G. (1982). Las estructuras antropológicas de lo imaginario. Madrid: Taurus.

Eliade, M. (1981). Lo sagrado y lo profano. Barcelona: Labor.

Ferrán, J. (2017). La ruptura posmoderna. Esteticismo y culturalismo en los poetas novísimos españoles. Sevilla: Renacimiento.

Flys Junquera, C. (2013). "Las piedras me empezaron a hablar": una aplicación literaria de la filosofía ecofeminista. Feminismo/s, 22, 89-112.

Flys Junquera, C., Marrero Henríquez, J. y Barella Vigal, J. (eds.). (2010). Ecocríticas. Literatura y medio ambiente. Madrid / Frankfurt / Orlando: Iberoamericana-Vervuert.

Forns-Broggi, R. (1998). ¿Cuáles son los dones que la naturaleza regala a la poesía latinoamericana? Hispanic Journal, 19, 2, 209-238.

----. (2012). Nudos como estrellas. ABC de la imaginación ecológica de nuestras Américas. Lima: Nido de Cuervos.

Frers, C. (2010). ¿Cuál es la importancia de la educación ambiental? [http://www.ecoportal.net/Temas-Especiales/Educacion-

Ambiental/cual es la importan cia de la educacion ambiental].

Galeano, J. (2003). Amazonia. Bogotá: Casa de Poesía Silva.

García Martínez, A. (1996). Los referentes axiológicos de la educación ambiental. Anales de Pedagogía, 14, 9-24.

\section{(c) (i) (2)}

La Revista Estudios es editada por la Universidad de Costa Rica y se distribuye bajo una Licencia Creative Commons Atribución-NoComercial-CompartirIgual 3.0 Costa Rica. Para más información envíe un mensaje a revistaestudios.eeg@ucr.ac.cr. 
Especial: Naturaleza amena y naturaleza agreste en las letras hispánicas

Garrigós, C. (2010). Claudio Guillén y los fenómenos naturales en la literatura: estudio de la relación entre tematología y ecocrítica. En Cots Vicente, M. y Monegal, A. (coord.). Actas del XVII Simposio de la Sociedad Española de Literatura General y Comparada. 1 (107-119). Barcelona: Sociedad Española de Literatura General y Comparada.

Glotfelty, C. y Fromm, H. (eds.). (1996). The Ecocriticism Reader. Landmarks in Literary Ecology. Athens / Londres: University of Georgia Press.

Guerra, O. (2006). Paisaje, identidad y existencia en la literatura canaria. En Marrero Henríquez, J. (ed.). Pasajes y paisajes. Espacios de vida, espacios de cultura. 69-88. Gran Canaria: Universidad de Las Palmas de Gran Canaria.

Hellpach, W. (1940). Geopsique. El alma humana bajo el influjo de tiempo y clima, suelo y paisaje. Madrid: Espasa-Calpe.

Hernández, F. (s.f.). Impacto ambiental de los invernaderos. [http://www.agrotecnologia-tropical.com/impacto ambiental invernaderos.html]

Huber, S. (1961). El imperio inca. Barcelona: Jano.

Íncer Barquero, J. (2003). Ausencia y presencia del poeta. En Cuadra, P. Poesía II (VII-XVI). Managua: Fundación Vida.

Juarroz, R. (1997). Decimocuarta poesía vertical; Fragmentos verticales. Buenos Aires: Emecé.

Kellert, S. y Wilson, E. (1993). The Biophilia Hypothesis. Washington DC: Island Press.

Kern, R. (2003). Ecocriticism. What is it Good For? En Branch, M. y Slovic, S. (eds.). The Isle Reader. Ecocriticism, 1993-2003. 258-281. Athens: University of Georgia Press.

Kibédi, A. (2000). Criterios para describir las relaciones entre palabra e imagen. En Monegal, A. (coord.). Literatura y pintura. 109-138. Madrid: Arco.

\section{(c) (i) (2)}

La Revista Estudios es editada por la Universidad de Costa Rica y se distribuye bajo una Licencia Creative Commons Atribución-NoComercial-CompartirIgual 3.0 Costa Rica. Para más información envíe un mensaje a revistaestudios.eeg@ucr.ac.cr. 
Especial: Naturaleza amena y naturaleza agreste en las letras hispánicas

López Grandolí, A. (2008). La escritura mirada. Una aproximación a la poesía experimental española. Madrid: Biblioteca Litterae Calambur.

Mainardi, L. (2015). Río adentro. Buenos Aires: Dunken.

Marrero Henríquez, J. (2010). Ecocrítica e hispanismo. En Flys Junquera, C., Marrero Henríquez, J. y Barella Vigal, J. (eds.). Ecocríticas. Literatura y medio ambiente. 193-217. Madrid / Frankfurt / Orlando: IberoamericanaVervuert.

Murphy, P. (2010). Prefacio. En Flys Junquera, C., Marrero Henríquez, J. y Barella

Vigal, J. (eds.). Ecocríticas. Literatura y medio ambiente. 11-13. Madrid / Frankfurt / Orlando: Iberoamericana-Vervuert.

Nana Tadoun, G. (2008). Antonio Colinas o la escritura como aventura circular: Poesía y transtextualidad desde su trilogía final (1992-2002). Tesis doctoral. Universidad de Salamanca.

Nixon, R. (2011). Slow Violence and the Environmentalism of the Poor. Massachusetts: Harvard University Press.

Orozco, O. (2000). Obra poética. Caracas: Fundación Biblioteca Ayacucho.

Ortega, J. (2009). Antología de la poesía hispanoamericana actual. México: Siglo $\mathrm{XXI}$.

Ostria, M. (2008). Una lectura ecocrítica de textos huidobrianos. Anales de Literatura Chilena, 9, 221-234.

Otto, R. (1925). Lo santo. Lo racional y lo irracional en la idea de Dios. Madrid: Revista de Occidente.

Pacheco, J. (1986). Tarde o temprano. México: Fondo de Cultura Económica.

Paredes, J. y McLean, B. (2000). Hacia una tipología de la literatura ecológica en español. Ixquic, 2, 1-37.

Parkinson Zamora, L. (1994). Narrar el apocalipsis: la visión histórica en la literatura estadounidense y latinoamericana contemporánea. México: FCE.

\section{(c) (i) (-)}

La Revista Estudios es editada por la Universidad de Costa Rica y se distribuye bajo una Licencia Creative Commons Atribución-NoComercial-CompartirIgual 3.0 Costa Rica. Para más información envíe un mensaje a revistaestudios.eeg@ucr.ac.cr. 
Especial: Naturaleza amena y naturaleza agreste en las letras hispánicas

Pastor, B. (1983). Discurso narrativo de la Conquista de América. La Habana: Casa de las Américas.

Paz, O. (1990). La otra voz. Poesía y fin de siglo. México: Seix Barral / Biblioteca Breve.

----. (1999). Obras completas. I. Barcelona: Galaxia Gutenberg.

Puglisi, M. (2011). Centinelas de la Tierra.

[http://mariozpuglisi.blogspot.com/2011/08/centinelas-de-la-tierra.html]

Quijano, Heber. (2015). El fuego y los vínculos cosmogónicos en "Ala del sur" de

Efraín Bartolomé. Contribuciones desde Coatepec, 29, 73-86.

Remacha, J. (ed.). (1990). Ernesto Cardenal para niños. Madrid: Ediciones de la Torre.

Riechmann, J. (1997). Ética y ecología: dos meditaciones. Madrid: Fundación $1^{\circ}$ de Mayo.

Rifkin, J. (2010). La civilización empática. Barcelona: Ediciones Paidós.

Rosenfeld, B. (2015). Sobre Río adentro. En Mainardi, L. Río adentro. 7-8. Buenos Aires: Dunken.

Ruecker, W. (1996). Literature and Ecology. An Experiment in Ecocriticism. En

Glotfelty, C. y Fromm, H. (eds.). The Ecocriticism Reader. Landmarks in Literary Ecology. 105-123. Athens / Londres: University of Georgia Press.

Ryden, K. (1993). Mapping the Invisible Landscape: Folklore, Writing and the Sense of Place. lowa: University of lowa Press.

Sarlo, G. (2017). El despertar de la conciencia ecológica a través de la literatura infantil y juvenil. Didáctica de la literatura y educación medioambiental. Revista Iberoamericana de Ciencia, Tecnología y Sociedad, 12 (35), 217228.

Scigaj, L. (1999). Sustainable Poetry. Four American Ecopoets. Lexington: University Press of Kentucky. 
Especial: Naturaleza amena y naturaleza agreste en las letras hispánicas

Tuan, Y. (1974). Topophilia: A Study of Environmental Perception, Attitudes and

Values. Nueva Jersey: Prentice-Hall.

Virilio, P. (2003). Unknown Quantity. Londres: Thames \& Hudson.

Vitale, I. (1998). Procura de lo imposible. México: Fondo de Cultura Económica.

Volkow, V. (2013). Litoral de tinta y otros poemas. Sevilla: Renacimiento.

VV.AA. (2011). Poesía ante la incertidumbre. Antología de nuevos poetas en español. Madrid: Visor.

White, S. (2002). El mundo más que humano en la poesía de Pablo Antonio Cuadra: Un estudio ecocrítico. Managua: Asociación Pablo Antonio Cuadra.

----. (2010). La homogeneización de la naturaleza en la obra de Gioconda Belli. Ecozon@, 1 (2), 97-112.

----- (ed.). (2014). El consumo de lo que somos. Muestra de poesía ecológica hispánica contemporánea. Madrid: Amargord.

Zapf, H. (2002). Literatur als kulturelle Ökologie: Zur kulturellen Funktion imaginativer Texte an Beispielen des amerikanischen Romans [Literature as Cultural Ecology: On the Cultural Function of Imaginative Texts, with Examples from American Literature]. Tübingen: Niemeyer.

----. (2010). Ecocriticism, Cultural Ecology, and Literary Studies. Ecozon@, 1 (1), 136-147.

\section{Notas}

' En este artículo, el adjetivo "hispánico" no se refiere estrictamente a lo español, sino que engloba las producciones escritas en lengua castellana en España, América Latina y otras latitudes.

ii La ecocrítica no puede olvidarse de que cualquier representación e interpretación de la naturaleza están atravesadas por el filtro humano. Resulta imposible deslindar la representación de la naturaleza de la naturaleza real pues, al verbalizarse esta a través del lenguaje, el texto ofrece una representación. Por eso, la ecocrítica debe tener presente que, al hablar de la naturaleza real, en realidad se habla de una naturaleza de carácter textual, y que es esta y no otra es la que el crítico literario debe abordar en su estudio (Garrigós, 2010). Como afirma Kern desde una perspectiva más moderada: "Closeness to nature, the escape from an anthropocentric perspective is a fiction"

\section{(c) (1) ()}

La Revista Estudios es editada por la Universidad de Costa Rica y se distribuye bajo una Licencia Creative Commons Atribución-NoComercial-CompartirIgual 3.0 Costa Rica. Para más información envíe un mensaje a 


\section{Especial: Naturaleza amena y naturaleza agreste en las letras hispánicas}

(2003, p. 277). Reconocer, por tanto, esta limitación permite al ecocrítico buscar la realidad natural a través de la estructura y el lenguaje de los textos, donde se revele la interacción entre naturaleza y cultura (Kern, 2003; Garrigós, 2010).

iii Término propuesto por Abram (1997) para referirse a todos aquellos elementos no humanos, pero descentrando lo humano como punto de referencia para considerar lo otro.

iv Los sitios Ramsar son aquellos que, gracias a la Convención Relativa a los Humedales de Importancia Internacional especialmente Hábitat de Aves Acuáticas, desde 1971 son conservados y utilizados racionalmente con base en acciones y cooperación locales, regionales, nacionales 0 internacionales.

v Dentro de los grados de unión morfológica entre la imagen y la palabra, Kibédi (2000) propone la interreferencia, cuando aquella y esta se refieren mutuamente, se encuentran separadas, pero en la misma página.

vi En la versión transcrita por Forns-Broggi en el apartado "Humedales" dice: "A cualquier edad llevan la vida reposada que sólo alcanzan las personas al jubilarse" (2012, p. 285).

vii En Forns-Broggi (2012) dice: "Los lagos que desean un reposo verdadero contratan gigantes para que los defiendan" (p. 285).

viii Al final del período, se suma en la versión de Forns-Broggi la oración: "Se habló mucho de él en esa época" (2012, p. 285).

ix Dice en Forns-Broggi: "Al ser lugares tan amables para vivir, el sueño de muchos en las ciudades es retirarse junto a un lago" (2012, p. 285).

$x$ "Hay quienes usan un lago tranquilo para engordar peces y exportarlos" en Forns-Broggi (2012, p. 285).

${ }^{x i}$ Con respecto al folklore, White (2002) cita las palabras de Ryden: "el folklore vivifica la geografía, otorgándole una vida llena de significados y revelándola como un socio hondamente conocido y activo en la vida" (1993, p. 57).

xii Uno de los atributos de lo numinoso es la maiestas: la majestad tremenda debida a su prepotencia y omnipotencia (Otto, 1925).

xiii Kellert y Wilson (1993) definen la biofilia como la necesidad de los seres humanos por relacionarse profunda e íntimamente con la biota vida de la naturaleza, con el propósito de realizarse, dentro de su proceso evolutivo, en términos estéticos, intelectuales, cognitivos y espirituales.

xiv Los símbolos diairéticos se refieren al héroe, la virilidad, las armas, la belicosidad y la purificación (Durand, 1982).

xv Los símbolos del progreso connotan el avance del ser humano a medida que este acepta lo positivo del tiempo (Durand, 1982).

xvi Flys Junquera sintetiza, de la siguiente forma, las ocho características que Karen Warren da a la ética ecofeminista: "1) es antinaturista (en el sentido que esta en contra de cualquier esencialismo o exclusión como el sexismo, racismo, etc.); 2) es una ética contextualista ya que no es una posición abstracta ni de principios pre-determinados, sino que tiene en cuenta las circunstancias del momento; 3) es una ética estructuralmente pluralista al presuponer y mantener las diferencias; 4) se concibe como una teoría en proceso que puede cambiar con el paso del tiempo; 5) es una ética inclusivista; 6) no pretende ofrecer un punto de vista objetivo sino que es más afín a una ecología social; 7) valora la ética del cuidado; y 8) implica una reconcepción de lo que significa ser humano y del comportamiento ético humano" (2013, p. 92).

xvii Binns señala que la herida abierta de la ironía y fractura de la analogía son patentes en la poesía de Pacheco. Para tal aserto, aquel entiende la ironía según Paz: "la hija del tiempo lineal, sucesivo e irrepetible; mientras la [analogía] es la manifestación del tiempo cíclico: el futuro está en el pasado y ambos en el presente" (1999, p. 482).

xviii El concepto de violencia lenta es propuesto por Nixon (2011), para referirse a la violencia que se incrementa con el tiempo y cuyas consecuencias se posponen por años, décadas o siglos; por

\section{(@) $\odot \Theta \odot$}

La Revista Estudios es editada por la Universidad de Costa Rica y se distribuye bajo una Licencia Creative Commons Atribución-NoComercial-CompartirIgual 3.0 Costa Rica. Para más información envíe un mensaje a revistaestudios.eeg@ucr.ac.cr. 


\section{Especial: Naturaleza amena y naturaleza agreste en las letras hispánicas}

ejemplo: la violencia verbal, la degradación ambiental, el cambio climático, la descongelación de los glaciares, la desertización y erosión de los suelos, los derrames de petróleo, la deforestación, la contaminación de los ríos y mares, entre otros.

xix Quijano (2015) interpreta este incendio en términos simbólico-religiosos, en tanto lo apocalíptico también deja ver una génesis y, por tanto, aquel cataclismo sería un incendio ritual, una situación nefasta y tremenda, que unifica, hermana a los predadores y a sus presas en el éxtasis de su carrera y muerte. El fuego sería un elemento transformador en sentido material y mítico-simbólico. Así, aquel autor concluye que "Ala del sur" constituye un poema cosmogónico.

${ }^{x x}$ Eliade se refiere grosso modo al hombre moderno como un ser arreligioso o desacralizado; sin embargo, afirma, esperanzado, que existen también seres humanos modernos que experimentan lo sagrado. Al respecto dice: "No hay hombre moderno, cualquiera que sea el grado de su irreligiosidad, que sea insensible a los 'encantos' de la Naturaleza. No se trata únicamente de los valores estéticos, deportivos e higiénicos otorgados a la Naturaleza, sino también de un sentimiento confuso y difícil de definir en el cual se reconoce todavía la reminiscencia de una experiencia religiosa degradada" (1981, p. 130).

xxi Estas datan de 232-8 a.C. y se ubican al sur del lago Xolotlán. Son las huellas fósiles de los pobladores indígenas y animales que, huyendo de una erupción, quedaron cubiertos por las cenizas y el fango volcánico. Dichas huellas son las evidencias más antiguas de existencia humana en Nicaragua.

xxii La frase "oráculo sobre" remite intertextualmente a la Biblia, pues dicha frase aparece con variación del nombre de la ciudad o país, en varios de los libros de esta.

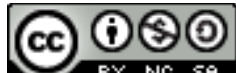

La Revista Estudios es editada por la Universidad de Costa Rica y se distribuye bajo una Licencia Creative Commons Atribución-NoComercial-CompartirIgual 3.0 Costa Rica. Para más información envíe un mensaje a 